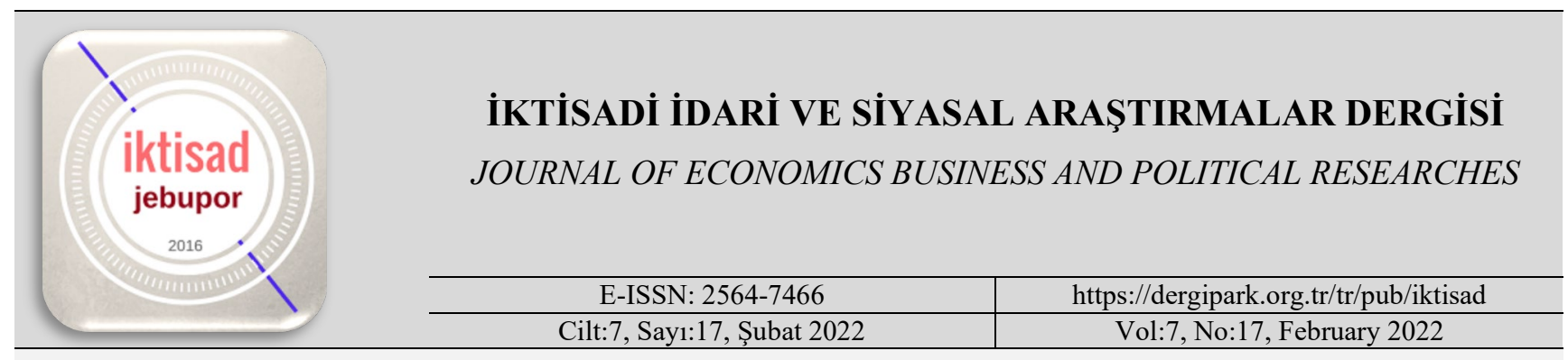

\title{
Consumer Adoption of Proximity Mobile Payment: An Empirical Cross-Cultural Study*
} Tüketicilerin Yakından Mobil Ödeme Kullanım Kabulü: Kültürrlerarası
Ampirik Bir Çalışma

DOI: https://doi.org/10.25204/iktisad.1055044

\section{Article Info}

Paper Type:

Research Paper

Received:

08.01 .2022

Accepted:

01.02 .2022

(C) 2022 JEBUPOR

All rights

reserved.

\section{(i) (2)}

Makale Bilgileri

Makale Türü:

Araştırma

Makalesi

Geliş Tarihi: 08.01.2022

Kabul Tarihi:

01.02.2022

(c) 2022 IKTISAD

Tüm haklarl

saklıdir.

\section{(1) (3)}

\section{Abstract}

The use of Proximity Mobile Payment (PMP) applications with several advantages over traditional payment methods is becoming more common. While a large diffusion of PMP is already apparent in South Korea, Germany is still lagging behind. The study examines the acceptance factors regarding the intention to use PMP in the mentioned countries to understand this divergence. A research model was developed to explain the behavioral intention, with an extensive literature analysis. An online survey was conducted, 186 Germans and 146 South Koreans participated the research. Results show that in both countries perceived usefulness, perceived risk, perceived compatibility, and personal innovativeness are the factors that determine the individuals' intention to use PMP. In addition, the social influence has an impact on the intention only in Germany, while the factors perceived ease of use and trust had no influence in both countries. Lastly, the influence of factors perceived compatibility and social influence on intention varies due to cultural differences. The study provides theoretical and managerial implications as well as an insight for further research.

Keywords: Consumer behavior, proximity mobile payment (PMP), behavioral intention, Germany, South Korea.

\section{Öz}

Yakından Mobil Ödeme (YMÖ) uygulamalarının kullanımı, geleneksel ödeme yöntemlerine göre birçok avantaj sağlaması nedeniyle giderek yaygınlaşmaktadır. Güney Kore'de YMÖ büyük bir yayılma gösterse de Almanya'da henüz yaygınlaşmadı̆̆ söylenebilir. Bu farklılı̆̆ anlamak için çalışma, her iki ülkede de YMÖ kullanma niyetiyle ilgili kabul faktörlerini incelemektedir. Kapsamlı bir literatür analizi ile YMÖ kullanım niyetini açıklamak için bir araştırma modeli geliştirilmiştir. Çevrimiçi bir anket yapılmış, araştırmaya 186 Alman ve 146 Güney Koreli katılmıştır. Sonuçlar, her iki ülkede de algılanan fayda, algılanan risk, algılanan uyumluluk ve kişisel yenilikçiliğin bireylerin davranışsal niyetini belirleyen faktörler olduğunu göstermiştir. Ayrıca sonuçlar, sosyal etkinin yalnızca Almanya'da YMÖ kullanma niyeti üzerinde bir etkisinin olduğunu, algılanan kullanım kolaylığ ve güven faktörlerinin her iki ülkede de anlamlı bir etkisinin olmadığını ortaya koymuştur. Son olarak, YMÖ kullanmaya yönelik davranışsal niyette, algılanan uyumluluk ve sosyal etki faktörlerinin etkilerinin kültür baz alınarak yapılan incelemede anlamlı olarak farklılaştı̆̆ı bulunmuştur. Çalışma, teorik ve yönetimsel çıkarımların yanı sıra izleyen araştırmalar için bazı bilgiler sunmaktadır.

Anahtar Kelimeler: Tüketici davranışı, yakından mobil ödeme (YMÖ), davranışsal niyet, Almanya, Güney Kore.

To Cite/ Atıf (APA): Fügl, M., and Kocagöz, E. (2022). Consumer adoption of proximity mobile payment: An empirical crosscultural study. Journal of Economics Business and Political Researches, 7(17), 173-201

\footnotetext{
${ }^{*}$ This study is a revised version of the study "Drivers of the use of proximity mobile payment: A comparative study of Germany and South Korea" prepared by Michael Fügl at the Faculty of Business Management and Economics at JMU Würzburg. Authors' Contributions: Fügl reviewed literature, carried out the field research, performed statistical analysis, and reported the results. Kocagöz provided her support at research design, verified analytical procedures, contributed to the interpretation of results, prepared this manuscript. Authors would like to extend their gratitude to Prof. Dr. Sascha Walter for his scientific support.

** ORCID M.Sc., Financial Services Consultant, Deloitte, Germany, michael.fuegl@web.de

*** ORCID Asst. Prof. Dr., Kahramanmaraş Sütçü İmam University, FEAS, Dept. of Business Administration, Turkey, elifsayin@yahoo.com
} 


\section{Extended Abstract}

\section{Background:}

The study examines the acceptance factors regarding the intention to use PMP in Germany and South Korea. This study is one of the first empirical studies focusing on the factors that determine consumer acceptance of MP/PMP services in Germany. In the field of MP, a comparison between Germany and an Asian country has not yet received enough consideration. Therefore, this study is a contribution to the related literature by exploring the factors that significantly influence consumers' acceptance of PMP and proposes a comprehensive research model based on an extensive literature review.

\section{Research Purpose:}

The aim of this study is to analyze the acceptance factors of PMP, to determine the constitutive factors that influence the individuals' intention to use PMP in Germany and in South Korea, and to compare the strengths of the effects of the variables on behavioral intention in order to detect differences between these countries.

\section{Methodology:}

A comprehensive research model was developed based on the literature reviewed, and following hypotheses were suggested: Perceived Usefulness-PU $\left(H_{1 a}\right)$, Perceived Ease of Use-PEU $\left(H_{3 a}\right)$, Perceived CompatibilityPC $\left(H_{4 a}\right)$, Social Influence-SI $\left(H_{5 a}\right)$, Trust $\left(H_{6 a}\right)$ and Perceived Innovativeness-PI $\left(H_{7 a}\right)$ positively; Perceived Risk-PR $\left(H_{2 a}\right)$ negatively influences the ITU-Intention to use PMP in Germany. PU $\left(H_{1 b}\right), \operatorname{PEU}\left(H_{3 b}\right), \operatorname{PC}\left(H_{4 b}\right)$, SI $\left(H_{5 b}\right)$, Trust $\left(H_{6 b}\right)$ and $\mathrm{PI}\left(H_{7 b}\right)$ positively; PR $\left(H_{2 b}\right)$ negatively influences ITU PMP in Germany. The impacts of PU, PEU and PI $\left(H_{1 c}, H_{3 c}, H_{7 c}\right)$ are stronger; and the impacts of PR, PC, SI and Trust $\left(H_{2 c}, H_{4 c}, H_{5 c}, H_{6 c}\right)$ are weaker on the intention to use PMP in Germany than in South Korea.

The convenience sampling method was used in the field research and survey method was used to collect data both in Germany and South Korea. The sample of the study consists of 332 participants. SmartPLS 3 software and IBM SPSS Statistics 26.0 were used to perform the analyses. The method of Partial Least Squares (PLS) was used to test the research hypotheses. The Multigroup Analysis (MGA) was performed to discover significant differences between the German and South Korean samples.

\section{Findings:}

The evaluation of the path model analysis of the German sample indicates that the effects of PU $\left(\mathrm{H}_{1 \mathrm{a}}\right), \mathrm{PR}$ $\left(\mathrm{H}_{2 \mathrm{a}}\right), \mathrm{PC}\left(\mathrm{H}_{4 \mathrm{a}}\right)$, SI $\left(\mathrm{H}_{5 \mathrm{a}}\right)$, and PI $\left(\mathrm{H}_{7 \mathrm{a}}\right)$ on ITU are significant. No significant effect on ITU was proven for PEU $\left(\mathrm{H}_{3 \mathrm{a}}\right)$ and trust $\left(\mathrm{H}_{6 \mathrm{a}}\right)$. In total, five of seven hypotheses were confirmed in the German sample. The Korean sample shows that the effects of PU $\left(\mathrm{H}_{1 b}\right)$, PR $\left(\mathrm{H}_{2 b}\right)$, PC $\left(\mathrm{H}_{4 b}\right)$ and PI $\left(\mathrm{H}_{7 b}\right)$ on ITU are significant. No statistically significant effect on ITU was found for the variables PEU $\left(\mathrm{H}_{3 \mathrm{~b}}\right)$, SI $\left(\mathrm{H}_{5 \mathrm{~b}}\right)$, and trust $\left(\mathrm{H}_{6 \mathrm{~b}}\right)$. In total, four out of seven hypotheses in the South Korean sample were confirmed.

According to MGA results, the significant difference arises in the effect of PC on ITU. As expected in hypothesis $\mathrm{H}_{4 \mathrm{c}}$, the influence of PC is stronger in South Korea, by which the ITU is positively influenced much more than in Germany. A further significant difference is apparent in the effect of SI on ITU. The path coefficient of the German sample is significantly higher than the Korean sample. Contrary to what was expected in hypothesis $\mathrm{H}_{5 \mathrm{c}}$, the SI is stronger in Germany, and the ITU is less positively influenced by SI in South Korea.

\section{Conclusion:}

The model developed based on literature review showed a strong predictive power for both German and South Korean sample. In both countries PU, PR, PC, and PI are the factors that determine the individuals' intention to use PMP. In Germany, the PU is the driver that influences the intention to use PMP most, followed by the PI, PC, and SI. In South Korea, PC is the driver with the most substantial impact, while the PI and PU also have an effect on the behavioral intention. In both countries, the PR also manifested itself as an inhibitor of PMP use intention. In addition, the SI has an impact on the intention only in Germany, while the factors PEU and trust had no influence in both countries. MGA revealed significant differences between the two countries only for the determinants PC and SI. The study discusses these results by comparing them with the findings at the related literature, comments on some implications and makes suggestions for further research. 


\section{Introduction}

Mobile payment (MP) is an alternative non-cash payment method based on the use of a smartphone or other mobile device such as a tablet (Handarkho and Harjoseputro, 2020: 285; Dahlberg et al., 2008: 166). It enables users to initiate, authorize, and confirm a financial transaction anytime and anywhere enabled by the mobile network or wireless technologies (Au and Kauffman, 2008: 141; Chandra et al., 2010: 562). Researchers classify MP into two types: proximity mobile payment (PMP) and remote mobile payment (RMP). PMP describes contactless payment at the PoS in supermarkets, retail stores, restaurants, or public transportation, utilizing a mobile device such as a smartphone (Zhou, 2013: 1086; Xin et al., 2015: 1; Humbani and Wiese, 2018: 412; Ramos-deLuna et al., 2019). To carry out a PMP transaction, the physical presence of the buyer at a sellers' premises is necessary (Handarkho and Harjoseputro, 2020: 288). When making contactless payments at the PoS, NFC is usually used by holding the mobile device close to the payment terminal and thereby completing the transaction (Taylor, 2016: 161). Payment through quick response (QR) codes is widespread in Asian countries contrary to the trend in Western countries; the corresponding code is scanned, and in this way, the payment process is initiated (Falk et al., 2016: 2418; Kerviler et al., 2016: 335). RMP, in contrast to PMP, allows consumers and sellers to be located in different places (Falk et al., 2016: 2418). The transaction is, therefore, subject to spatial separation without direct interaction between the two parties (Smart Card Alliance, 2011: 10). RMP is made possible by less novel technologies such as wireless broadband technology or via SMS (Shin and Lee, 2014: 1615; Kerviler et al., 2016: 335). Wireless broadband technology helps to make online purchases over the mobile Internet, while SMS can also be used to initiate a payment transaction from any location (Shin and Lee, 2014: 1615).

Forecasts indicate that the market regarding worldwide transactions will reach 4.574 trillion US dollar by the end of 2023 at a compound annual growth rate of 33.8\% between 2017 and 2023 (Statista, 2016; Allied Market Research, 2018). Nevertheless, the usage of MP is still in its infancy in various countries, such as Germany. Even though Germany has almost 58 million smartphone owners (Statista, 2019), most smartphones are equipped with the technology required for MP, and three out of four point of sale (PoS) terminals have the necessary infrastructure; the use of MP has so far been relatively low (Balz, 2019). According to the market research agency eMarketer (2019), only $12.5 \%$ of all smartphone users in Germany have executed an MP transaction in the last six months. In contrast, the adoption in Asian countries such as South Korea is much higher and amounts to 36.7\% of all smartphone users. According to another market report, MP is increasing in South Korea and mobile/digital wallets are being quickly adopted by younger generations (Worldpay, n.d.).

The aim of this study is to examine factors affecting the intention to use PMP in Germany as well as in South Korea. In the field of MP, culture-comparative studies are rare (e.g., Martens et al., 2017; Fan et al., 2018; Tan et al., 2019), and a comparison between Germany and an Asian country has not yet received enough consideration. The reason of considering this comparison is, despite the minor differences in their technological infrastructure, there are large variations in the adoption of MP between these countries. According to Crabbe et al. (2009), culture-comparative studies are useful to explore cultural and specific social differences of countries, which can often explain differences in the acceptance of technology. Sanakulov and Karjaluoto (2017) found that cultural differences play an essential role in the formation of intentions to use smartphones. Most recently, Akhtar et al. (2019) found in their China Pakistan comparative study that culture plays a significant role in the intention to use mobile banking.

On the other hand, the MP literature is increasing substantially, but the research is still concentrated in countries such as China (e.g., Yang et al., 2015; Ya et al., 2017; Su et al., 2018; Liu et al., 2019a; Lu and Lu, 2020), France (e.g., Dutot, 2015; Koenig-Lewis et al., 2015; Kerviler et al., 2016), Spain (e.g., Liébana-Cabanillas et al., 2014; Liébana-Cabanillas et al., 2015a; LiébanaCabanillas and Lara-Rubio, 2017; Liébana-Cabanillas et al., 2017; Liébana-Cabanillas et al., 2018), 
and the United States (e.g., Bailey et al., 2017; Ozturk et al., 2017; Park et al., 2018; Bailey et al., 2020; Zhang and Mao, 2020). Schierz et al. (2010) and Martens et al. (2017) examined the factors that determine consumer acceptance of MP services in Germany, and Finken and Heiduk (2021) investigated the factors affecting the adoption of PMP, with a specific focus on Apple Pay. No other empirical study has so far dealt with consumer acceptance of MP/PMP in Germany. Therefore, this study is addressing a contribution to the related literature by exploring the factors that significantly influence consumers' acceptance of PMP in Germany and South Korea. From theoretical and empirical points of view, the study proposes a model based on an extensive literature analysis. The study also incorporates Hofstede's (1991) cultural dimensions and explores the differences in the consumer acceptance factors, namely the mechanism of their influences on the behavioral intention. It is expected that the study contributes to the field with its theoretical and empirical approach and findings.

\section{Literature Review}

Researchers have been investigating the acceptance of MP services to identify the most significant factors that determine consumers' intention to use (e.g., Mallat, 2007; Schierz et al., 2010; Shin and Lee, 2014; Liébana-Cabanillas et al., 2018; Lee, 2019; Zhang and Mao, 2020). Variables such as perceived usefulness, performance expectancy, perceived risk, privacy concern, perceived technology security, perceived ease of use, effort expectancy, perceived compatibility, facilitating conditions, social influence, trust, personal innovativeness, consumer innovativeness, technological anxiety, perceived cost, price value, perceived enjoyment were found to be affecting the intention to use MP. A total of 46 articles $^{1}$ were synthesized in a concept matrix after reviewing the literature, (Table 1) in accordance with Webster and Watson (2002: 16) in order to provide a basic overview of the articles included.

Table 1. Overview of literature

\begin{tabular}{|l|l|c|c|l|}
\hline $\begin{array}{l}\text { Region } \\
\text { Country }\end{array}$ & Author(s) & $\begin{array}{c}\text { Published } \\
\text { year }\end{array}$ & $\begin{array}{c}\text { Sample } \\
\text { size }\end{array}$ & Theoretical base model \\
\hline Africa & & & & \\
\hline Kenya & Nyaboga et al. & 2015 & 680 & TAM \\
\hline $\begin{array}{l}\text { South Africa, } \\
\text { Germany }\end{array}$ & Martens et al. & 2017 & 444 & TAM, TRI \\
\hline South Africa & Humbani and Wiese & 2018 & 426 & TRI \\
\hline South Africa & Verkijika & 2020 & 325 & Affective Response Model \\
\hline Asia & & & & \\
\hline China & Zhou & 2011 & 277 & TAM \\
\hline China & Yang et al. & 2015 & 310 & TAM \\
\hline China & Wu et al. & 2017 & 484 & Affect Heuristic Theory \\
\hline China & Su et al. & 2017 & 922 & TAM, DOI \\
\hline $\begin{array}{l}\text { China, } \\
\text { Malaysia }\end{array}$ & Tan et al. & 2019 & 311 & TPB \\
\hline China & Liu et al. . & $2019 \mathrm{a}$ & 245 & TAM \\
\hline China & Lu and Lu & 2020 & 380 & TAM \\
\hline India & Thakur and Srivastava & 2013 & 803 & TAM \\
\hline India & Chawla and Joshi & 2019 & 744 & UTAUT, TAM \\
\hline Indonesia & Handarkho and Harjoseputro & 2020 & 459 & Push-Pull-Mooring Theory \\
\hline Iran & Keramati et al. & 2012 & 623 & Own framework \\
\hline Jordan & Qasim and Abu-Shanab & 2016 & 251 & UTAUT \\
\hline Malaysia & Leong et al. & 2013 & 262 & TAM \\
\hline
\end{tabular}

\footnotetext{
${ }^{1}$ Articles were found in the online databases EBSCO, Science Direct, Springer, and Emerald with key terms such as mpayment, MP, proximity mobile payment, PMP, in-store mobile payment, NFC mobile payment as well as mobile wallet. $76 \mathrm{MP}$ articles were found, a total of 46 articles were selected from 34 different journals, and the rest is excluded from the study that they not meet certain criteria (such as theoretical articles or articles addressing RMP).
} 
Table 1 (Cont.). Overview of literature

\begin{tabular}{|l|l|c|c|l|}
\hline Malaysia & Teo et al. & 2015 & 194 & UTAUT \\
\hline Qatar & Musa et al. & 2015 & 169 & UTAUT \\
\hline South Korea & Shin & 2009 & 296 & TAM \\
\hline South Korea & Kim et al. & 2010 & 269 & TAM, DOI \\
\hline South Korea & Shin and Lee & 2014 & 585 & TAM, TRI \\
\hline South Korea & Lee & 2019 & 528 & UTAUT \\
\hline Thailand & Sellitto et al. & 2016 & 529 & TAM \\
\hline Europe & & & & \\
\hline Finland & Mallat & 2007 & 39 & Own framework \\
\hline France & Koenig-Lewis et al. & 2015 & 316 & UTAUT2 \\
\hline France & Dutot & 2015 & 320 & TAM \\
\hline France & Kerviler et al. & 2016 & 179 & Theory of Perceived Value \\
\hline Germany & Schierz et al. & 2010 & 1447 & TAM \\
\hline Portugal & Oliveira et al. & 2016 & 301 & UTAUT2 \\
\hline Spain & Liébana-Cabanillas et al. & 2014 & 2012 & TAM \\
\hline Spain & Liébana-Cabanillas et al. & $2015 \mathrm{a}$ & 201 & TAM \\
\hline Spain & Liébana-Cabanillas et al. & $2015 \mathrm{~b}$ & 168 & TAM \\
\hline Spain & Ramos-de-Luna et al. & 2016 & 191 & TAM \\
\hline Spain & Liébana-Cabanillas et al. & $2015 \mathrm{c}$ & 2012 & TAM \\
\hline Spain & Ramos-de-Luna et al. & 2015 & 287 & TAM \\
\hline Spain & Liébana-Cabanillas et al. & 2017 & 191 & TAM \\
\hline Turkey & Daştan and Gürler & 2016 & 225 & TAM \\
\hline $\begin{array}{l}\text { United } \\
\text { Kingdom }\end{array}$ & Slade et al. & 2015 & 244 & UTAUT2 \\
\hline North America & & & & \\
\hline United States & Bailey et al. & 2017 & 240 & TAM \\
\hline United States & Ozturk et al. & 2017 & 412 & Valence Theory \\
\hline United States & Zhang and Mao & 2019 & 394 & TAM, TRA \\
\hline United States & Bailey et al. & 2020 & 357 & TAM \\
\hline Oceania & & & \\
\hline Australia & Gao and Waechter & 2017 & 851 & TAM, Valence Theory \\
\hline New Zealand & Xin et al. & & 423 & TAM \\
\hline South America & & & \\
\hline Brazil & Ramos-de-Luna et al. & & \\
\hline
\end{tabular}

The results of the applied research models in the studies shown at Table 1 were examined to identify the significant determinants of the behavioral intention. The factors that do not interact directly with the dependent variable intention were excluded. If the research model of the respective publication was applied in two different countries, the results of the direct factors from each country were included individually in the overview. All variables were systematically combined in Table 2. 52 different determinants were used as direct variables of behavioral intention, which were aggregated into ten categories. In total, the determinants were used 190 times and were reviewed by a total of 21,628 respondents. The majority of these articles dealt with variables aggregated under PU (73.9\%), PR (67.4\%), PEU (63.0\%), PC (56.5\%), and SI (52.2\%) to explain the intention. Factors assignable to the categories trust $(28.3 \%)$ and PI $(23.9 \%)$ were used in about a quarter of all publications and price value $(15.2 \%)$ in every fifth article. Less frequently used were determinants assignable to the category perceived enjoyment (15.2\%), and others $(10.9 \%)$. 
Table 2. Overview of determinant analysis

\begin{tabular}{|c|c|c|c|c|c|}
\hline $\begin{array}{l}\text { Aggregated determinant } \\
\text { Determinant }\end{array}$ & $\begin{array}{c}\text { Hypothesized } \\
\text { effect }\end{array}$ & $\mathbf{n}$ & $\%$ of overall articles & $\begin{array}{l}\text { Number of } \\
\text { significance }\end{array}$ & $\begin{array}{r}\text { \% share of } \\
\text { significance }\end{array}$ \\
\hline Perceived Usefulness (PU) & & 34 & 73.9 & 29 & 85.3 \\
\hline Perceived Usefulness & + & 22 & 47.8 & 18 & 81.8 \\
\hline Performance Expectancy & + & 6 & 13.0 & 5 & 83.3 \\
\hline Relative Advantage & + & 2 & 4.3 & 2 & 100.0 \\
\hline Perceived Benefit & + & 2 & 4.3 & 2 & 100.0 \\
\hline Perceived Value & + & 1 & 2.2 & 1 & 100.0 \\
\hline Utilitarian Value & + & 1 & 2.2 & 1 & 100.0 \\
\hline Perceived Risk (PR) & & 31 & 67.4 & 26 & 83.9 \\
\hline Perceived Risk & - & 15 & 32.6 & 13 & 86.7 \\
\hline Security & + & 9 & 19.6 & 6 & 66.7 \\
\hline Privacy Concern & - & 2 & 4.3 & 2 & 100.0 \\
\hline Privacy & - & 1 & 2.2 & 1 & 100.0 \\
\hline Privacy Risk & - & 1 & 2.2 & 1 & 100.0 \\
\hline Perceived Privacy Risk & - & 1 & 2.2 & 1 & 100.0 \\
\hline Perceived Technology Security & + & 1 & 2.2 & 1 & 100.0 \\
\hline Perceived Information Security & + & 1 & 2.2 & 1 & 100.0 \\
\hline Perceived Ease of Use (PEU) & & 29 & 63.0 & 19 & 65.5 \\
\hline Perceived Ease of Use & + & 16 & 34.8 & 11 & 68.8 \\
\hline Effort Expectancy & + & 5 & 10.9 & 1 & 20.0 \\
\hline Convenience & + & 5 & 10.9 & 5 & 100.0 \\
\hline Perceived Performance Speed & + & 1 & 2.2 & 1 & 100.0 \\
\hline Perceived Transaction Speed & + & 1 & 2.2 & 1 & 100.0 \\
\hline Perceived Transaction & + & 1 & 2.2 & 0 & 0.0 \\
\hline Convenience & & & & & \\
\hline Perceived Compatibility (PC) & & 26 & 56.5 & 19 & 73.1 \\
\hline Perceived Compatibility & + & 10 & 21.7 & 10 & 100.0 \\
\hline Individual Mobility & + & 4 & 8.7 & 1 & 25.0 \\
\hline Facilitating Conditions & + & 5 & 10.9 & 2 & 40.0 \\
\hline Network Externalities & + & 3 & 6.5 & 2 & 66.7 \\
\hline Perceived Behavioral Control & + & 2 & 4.3 & 2 & 100.0 \\
\hline Habit & + & 2 & 4.3 & 2 & 100.0 \\
\hline Social Influence (SI) & & 24 & 52.2 & 21 & 87.5 \\
\hline Social Influence & + & 10 & 21.7 & 8 & 80.0 \\
\hline Subjective Norms & + & 9 & 19.6 & 8 & 88.9 \\
\hline External Influences & + & 3 & 6.5 & 3 & 100.0 \\
\hline Socio-cultural Influence & + & 1 & 2.2 & 1 & 100.0 \\
\hline Perceived Herd Behavior & + & 1 & 2.2 & 1 & 100.0 \\
\hline Trust & & 13 & 28.3 & 12 & 92.3 \\
\hline Trust & + & 10 & 21.7 & 9 & 90.0 \\
\hline Trust in Provider & + & 1 & 2.2 & 1 & 100.0 \\
\hline Initial Trust & + & 1 & 2.2 & 1 & 100.0 \\
\hline System Trust & + & 1 & 2.2 & 1 & 100.0 \\
\hline Personal Innovativeness (PI) & & 11 & 23.9 & 8 & 72.7 \\
\hline Personal Innovativeness & + & 7 & 15.2 & 5 & 71.4 \\
\hline Consumer Innovativeness & + & 1 & 2.2 & 1 & 100.0 \\
\hline Internet Experience & + & 1 & 2.2 & 1 & 100.0 \\
\hline Technological Anxiety & - & 1 & 2.2 & 0 & 0.0 \\
\hline Knowledge & + & 1 & 2.2 & 1 & 100.0 \\
\hline Price Value & & 10 & 21.7 & 6 & 60.0 \\
\hline Price Value & + & 7 & 15.2 & 4 & 57.1 \\
\hline Perceived Cost & - & 2 & 4.3 & 1 & 50.0 \\
\hline Perceived Financial Risk & - & 1 & 2.2 & 1 & 100.0 \\
\hline Perceived Enjoyment & & 7 & 15.2 & 2 & 28.6 \\
\hline Perceived Enjoyment & + & 3 & 6.5 & 1 & 33.3 \\
\hline Hedonic Motivation & + & 2 & 4.3 & 0 & 0.0 \\
\hline Positive Emotions & + & 1 & 2.2 & 1 & 100.0 \\
\hline Discomfort & - & 1 & 2.2 & 0 & 0.0 \\
\hline Others & & 5 & 10.9 & 3 & 60.0 \\
\hline Deal Proneness & + & 1 & 2.2 & 1 & 100.0 \\
\hline Affect & + & 1 & 2.2 & 1 & 100.0 \\
\hline Anticipated Regret & + & 1 & 2.2 & 1 & 100.0 \\
\hline Self-Efficacy & + & 1 & 2.2 & 0 & 0.0 \\
\hline Optimism & + & 1 & 2.2 & 0 & 0.0 \\
\hline
\end{tabular}




\section{Research Design}

The aim of this study is to find out the factors that significantly influence the consumers' intention to use PMP in Germany and in South Korea, and to what extent they differ between the countries. Based on the literature reviewed, the following model was developed (Figure 1). The intention is of central importance as a dependent variable in the model and is defined in this context as the probability that a person will use PMP, i.e. MP at the PoS.

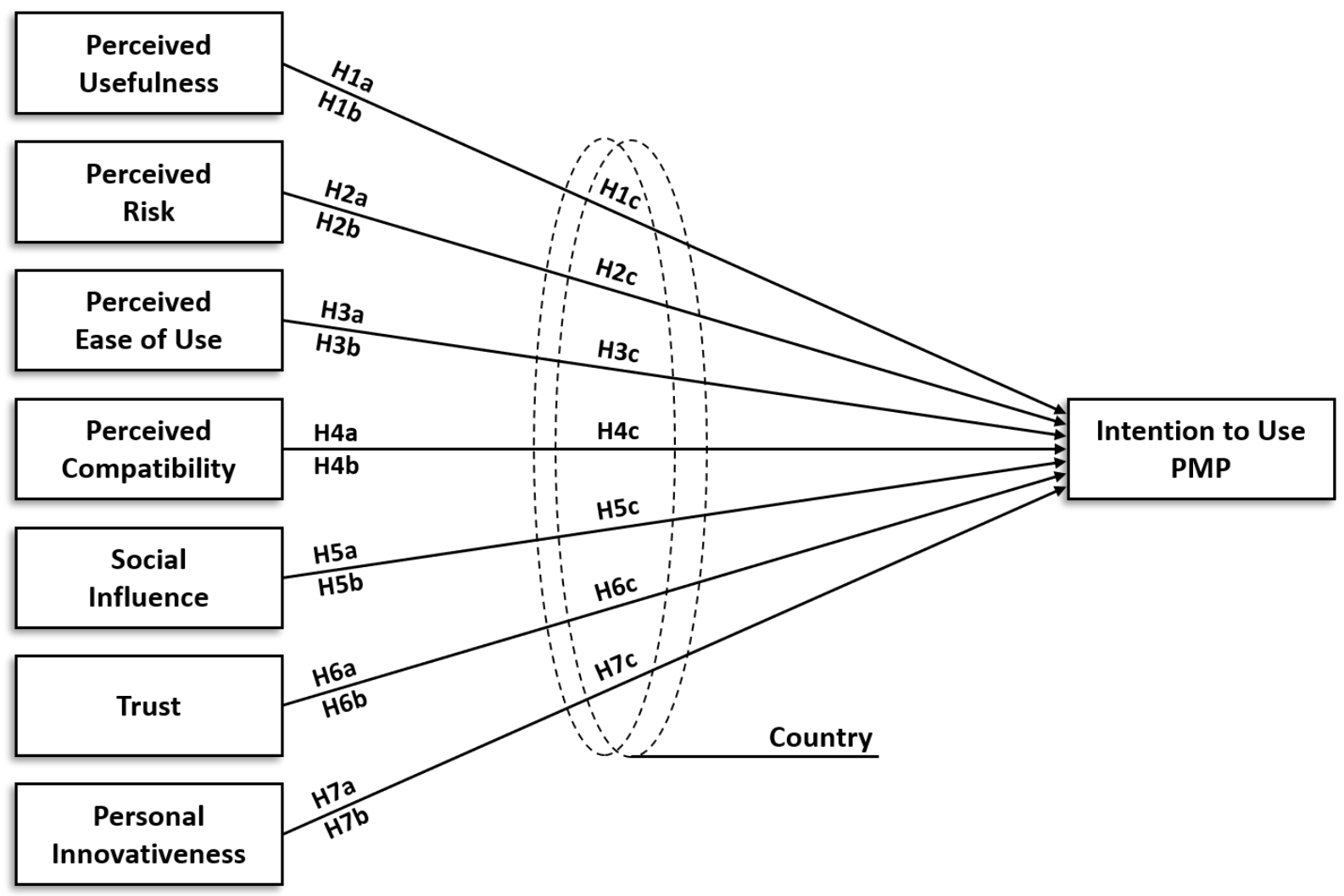

Figure 1. Research model

Perceived usefulness (PU) refers specifically to the extent to which MP is useful and brings an advantage when used as a means of payment (Liébana-Cabanillas et al., 2018: 121). PU is greater when the users' performance in a transaction is improved and it is strongly connected to the transaction efficiency and enhancing shopping convenience (Su et al., 2018: 188; Bailey et al., 2020: 147). Researches show that PU has a significant positive effect on the intention to use MP. Since PMP uses technologies such as NFC that eliminate the need to carry cash and cards while providing a faster payment method, it is expected that such benefits will increase the PU of a transaction for the user and, consequently, the intention to use PMP. Several studies (e.g., Koenig-Lewis et al., 2015; Liébana-Cabanillas et al., 2018; Liu et al., 2019b) have already demonstrated the positive and significant effect of PU on the intention to use MP. Therefore, following hypotheses were proposed:

$H_{\text {la: }}$ PU positively influences the intention to use PMP in Germany.

$H_{l b:}$ PU positively influences the intention to use PMP in South Korea.

Perceived risk (PR) plays a major role regarding MP since the use of innovative technology is often associated with a high risk concerning privacy and security (Pavlou, 2003: 103). In particular, the aspect of privacy is relevant since a large amount of private data, such as bank details, PIN codes, location, or transaction data are involved in the background of MP transactions (Yang et al., 2015: 257). According to Bauer (1960), PR is a factor in consumer behavior that becomes apparent when consumers are confronted with uncertainties as a result of using a product. Even if users who are familiar with online banking, for example, know that the private data is secure and account hacking 
is very rare, it can still come into consideration when dealing with PMPs. The terminals that receive mobile transaction-relevant information absorb more data from PMPs than from credit cards, raising concerns among potential consumers about privacy and monetary loss (Koenig-Lewis et al., 2015: 542; Su et al., 2018: 190). Studies show that perceived privacy and security risks of PMP transactions are direct determinants of the intention to use and have a significant impact on intention (e.g., Slade et al., 2015; Kerviler et al., 2016; Liu et al., 2019b). In 83.9\% of studies examined in this study displayed a negative influence of PR on intention, accordingly following hypotheses were proposed:

\section{$H_{2 a}: P R$ negatively influences the intention to use PMP in Germany.}

$H_{2 b}$ : PR negatively influences the intention to use PMP in South Korea.

Perceived ease of use (PEU) describes the extent to which a person believes that using a system is free of effort. In PMP context, it describes the ease of making a payment at the PoS using a smartphone. However, the installation and configuration of the MP application requires time and effort compared to conventional payment alternatives (Liu et al., 2019b: 326). When the less effort is required and the technology is seen as user-friendly, the willingness to use it increases. This effect was also confirmed in numerous earlier studies in the field of MP (e.g., Keramati et al., 2012; Su et al., 2018; Liu et al., 2019b). Although researchers such as Shin and Lee (2014), Koenig-Lewis et al. (2015), and Liébana-Cabanillas et al. (2018) concluded that there is no significant influence of PEU on consumers' intention, in about $65.5 \%$ of 29 studies reviewed in this study which examined the influence of PEU, confirmed a significant positive effect. Therefore, following hypotheses were proposed:

\section{$H_{3 a}: P E U$ positively influences the intention to use PMP in Germany. \\ $H_{3 b}$ : PEU positively influences the intention to use PMP in South Korea.}

Perceived compatibility (PC) indicates the extent to which a technology corresponds to the previous experiences and values of a user (Venkatesh et al., 2003: 454). A high level of PC among users is central to the diffusion of technologies, as this can reduce potential uncertainties related to use by meeting individual needs (Su et al., 2018: 188). According to Chen (2008), the needs of users about their lifestyle and shopping habits are particularly relevant to this. With new technology, potential users usually must acquire knowledge that is relevant for use (Zhu et al., 2006: 603). However, experience with related technologies, such as the use of NFC credit cards, is often helpful here, as this helps to identify the compatibility between existing and new technologies (Su et al., 2018: 189). Previous research showed that $\mathrm{PC}$ is one of the most important factors in predicting the intention to use MP, since a significant positive correlation was found in $73.1 \%$ of all empirical studies reviewed in this study (e.g., Schierz et al., 2010; Ramos-de-Luna et al., 2016; Su et al., 2018). Following hypotheses were proposed:

\section{$H_{4 a}: P C$ positively influences the intention to use PMP in Germany. \\ $H_{4 b}:$ PC positively influences the intention to use PMP in South Korea.}

Social influence (SI) describes the magnitude to which the social environment influences the individual in the decision to use MP (Shin, 2009: 1347). This is mainly done by consulting the social network in relation to new technologies to reduce fears and insecurities (Slade et al., 2015: 212). The construct SI represents not only the influence of the social milieu but also the pressure felt by the consumer to use PMP. The determinant SI is present under various names in other research models and was empirically used in $52.5 \%$ of the 46 articles reviewed. Although there were some exceptions in literature (e.g., Teo et al., 2015; Oliveira et al., 2016), SI had positively affected the intention to use in several studies (e.g., Slade et al., 2015; Qasim and Abu-Shanab, 2016; Lee, 2019). Significant positive influences found in $87.5 \%$ of 46 studies examined in this study. Following hypotheses were proposed:

$H_{5 a}$ : SI positively influences the intention to use PMP in Germany.

$H_{5 b}$ : SI positively influences the intention to use PMP in South Korea. 
Trust with regard to MP services (trust in provider, initial trust, system trust) plays also an important role since a financial transaction is very personal, sensitive, and confidential (van der Heijden et al., 2003: 42). If the user has confidence in the ability of the MP service provider to carry out such transactions securely as well as with integrity, this can have a positive effect on the behavioral intention (Zhou, 2014: 940). In this context, an individual who carries out a financial transaction at the PoS trusts that the transaction will be completed as anticipated and compliant with data protection. As a result, a high level of trust on the part of an individual could indicate that the uncertainty and concern associated with PMP use are mitigated and vice versa for a low level of trust. This variable was empirically studied in 13 of 46 articles reviewed. Although a comparative study of Sellitto et al. (2016) comparing potential and current users of MP showed that the perceived trust has no significant effect on the intention for current users., the rest of the studies found significant and positive effect of trust on MP use intention (e.g., Keramati et al., 2012; Qasim and Abu-Shanab, 2016; Gao and Waechter, 2017). Therefore, following hypotheses were proposed:

$H_{6 a}:$ Trust positively influences the intention to use PMP in Germany.

$H_{6 b}$ : Trust positively influences the intention to use PMP in South Korea.

Considering that PMP in stationary retail is an innovative substitute for cash and credit cards, the final variable included in the model is the personal innovativeness (PI). PI is generally defined as an individual willingness to test new technologies (Kalinic and Marinkovic, 2016: 370). In MP perspective, PI indicates how rapidly a user uses and accepts it (Handarkho and Harjoseputro, 2020: 290). The PI of an individual can indicate the acceptance of PMP, as it is expected that people with a high degree of innovativeness have a higher propensity to try the new technology. Several studies showed a significant positive influence of PI on the MP use intention (e.g., Oliveira et al., 2016; Ramos-de-Luna et al., 2016; Handarkho and Harjoseputro, 2020). Following hypotheses were proposed:

$H_{7 a}:$ PI positively influences the intention to use PMP in Germany.

$H_{7 b}$ : PI positively influences the intention to use PMP in South Korea.

Further seven hypotheses were proposed by taking the following issues into consideration for the cross-cultural comparison: (1) Sun and Zhang (2006: 72) showed that the impact of PU on the intention to use certain technology is greater in countries that have a lower power distance and have a more individualistic culture. This is justified by the fact that people in this kind of society are more independent and come to their own decisions (Im et al., 2011: 1). Sun and Zhang (2006: 72) found that the effect of PU on the intention to use is lower in countries with a more feminine and high uncertainty avoidance culture. (2) PR is different in various countries due to diverging cultural characteristics (Hsee and Weber, 1999). Uncertainty avoidance, which is closely related to the concept of risk, plays an important role in the acceptance of technologies. In connection with the use of PMP, potential users may be exposed to uncertainties regarding their private data as well as financial loss. Individuals in a culture with a high extent tend to avoid risks more than those in a culture with a low extent of uncertainty avoidance (Xin et al., 2015: 2). (3) Straub et al. (1997: 11) showed that the effect of PEU on technology acceptance is stronger in the USA than in Japan. Smilarly, Im et al. (2011: 8) found that the effect of PEU is stronger in more individualistic countries. (4) By reviewing technology acceptance research in Germany (Koenig-Lewis et al., 2010), China (Su et al., 2018), and India (Chawla and Joshi, 2019), which tested the effect of PC on the behavioral intention, some differences in the strength of the effect were observed. The effect is moderately weak in Germany, which is less power-distant and individualistic, and is stronger in China and India which have high power distance and collectivist cultures. (5) A diverging effect of SI on PMP use intention was also pointed out in some studies (Sun and Zhang, 2006; Im et al., 2011). Im et al. (2011: 8) studied South Korea and the USA and revealed that SI is greater in a country with a less individualistic culture. (6) Xin et al. (2015: 7) found that users from a high uncertainty avoidance culture have less trust in MP technology than those from a low uncertainty avoidance culture. (7) According to Park 
and Jun (2003: 537), individualism, masculinity, and uncertainty avoidance can be connected to PI. This is in line with Steenkamp et al., (1999) who suggest that individuals from "a high individualist, masculine, and low uncertainty avoidance' culture have a higher PI. This is consistent with the findings of Thatcher et al. (2003: 74), who observed that users of information technology with a low degree of uncertainty avoidance are more innovative than users with a high degree. Accordingly, following hypotheses were proposed:

$H_{1 c}$ : The impact of PU on the intention to use PMP is stronger in Germany than in South Korea. $H_{2 c}$ : The impact of PR on the intention to use PMP is weaker in Germany than in South Korea. $H_{3 c}$ : The impact of PEU on the intention to use PMP is stronger in Germany than in South Korea.

$H_{4 c}$ : The impact of PC on the intention to use PMP is weaker in Germany than in South Korea. $H_{5 c}$ : The impact of SI on the intention to use PMP is weaker in Germany than in South Korea. $H_{6 c}$ : The impact of trust on the intention to use PMP is weaker in Germany than in South Korea. $H_{7 c}$ : The impact of PI on the intention to use PMP is stronger in Germany than in South Korea.

\subsection{Questionnaire}

The questionnaire ${ }^{2}$ starts with an introduction to the concept of MP at the PoS, i.e. PMP, followed by an animated illustration of an application case at a PoS terminal, to provide the participants with a clear understanding of PMP before they answer questions. The questionnaire divides into three sections. In the first section, screening questions focused on smartphone ownership and knowledge about MP at the PoS, thus helping to exclude non-owners of smartphones from the study. In the second section, demographic information of the respondents are queried. The last part includes a 7point scale ( $1=$ "strongly disagree", 7="strongly agree") consisting of 30 statements. All items, including their sources, are listed in Table 3.

\footnotetext{
${ }^{2} \mathrm{~A}$ Korean professor who speaks both Korean and German translated the form. The back-translation procedure was employed. The Korean version was translated back into German by a Korean-German fellow student who is a native speaker of both languages. A pilot survey was conducted and based on the pre-test, two questions were reformulated.
} 
Table 3. Measurement Items

\begin{tabular}{|c|c|}
\hline $\begin{array}{l}\text { Construct } \\
\text { Item }\end{array}$ & References \\
\hline $\begin{array}{l}\text { Perceived Usefulness (PU) } \\
\text { PU1 - I believe that using PMP enables me to pay more quickly. } \\
\text { PU2 - I believe that using PMP enhances me to pay more conveniently. } \\
\text { PU3 - I believe that using PMP is useful for me. } \\
\text { PU4 - I believe that using PMP increases my productivity. }\end{array}$ & $\begin{array}{l}\text { Adapted from Davis } \\
\text { (1989) }\end{array}$ \\
\hline Perceived Risk (PR) & Adapted from \\
\hline PR1 - I believe that using PMP is risky. & \\
\hline PR2 - I believe that using PMP is associated with a high loss potential. & Pavlou (2003), and \\
\hline $\begin{array}{l}\text { PR3 - I believe that using PMP is associated with much uncertainty. } \\
\text { PR4 - I believe that my MP transaction data is also known to unknown third parties. }\end{array}$ & Chandra et al. (2010) \\
\hline $\begin{array}{l}\text { Perceived Ease of Use (PEU) } \\
\text { PEU1 - I believe that when I use PMP, the process is clear and understandable. } \\
\text { PEU2 - I believe that it is easy for me to become skillful at using PMP. } \\
\text { PEU3 - I believe that using PMP is easy to use. } \\
\text { PEU4 - I believe that learning to use PMP is easy for me. }\end{array}$ & $\begin{array}{l}\text { Adapted from Davis } \\
\text { (1989) }\end{array}$ \\
\hline $\begin{array}{l}\text { Perceived Compatibility (PC) } \\
\text { PC1 - I believe that using PMP fits well with my lifestyle. } \\
\text { PC } 2 \text { - I believe that using PMP fits well with the way that I like to conduct my payment } \\
\text { transactions. } \\
\text { PC } 3 \text { - I believe that using PMP is completely compatible with my current situation. }\end{array}$ & $\begin{array}{l}\text { Adapted from Chen } \\
\text { (2008), Moore and } \\
\text { Benbasat (1991), and } \\
\text { Schierz et al. (2010) }\end{array}$ \\
\hline $\begin{array}{l}\text { Social Influence (SI) } \\
\text { SI1 - People who are important to me think that I should use PMP. } \\
\text { SI2 - People who influence my behavior think that I should use PMP. } \\
\text { SI3 - People whose opinions that I value prefer that I use PMP. }\end{array}$ & $\begin{array}{l}\text { Adapted from } \\
\text { Venkatesh } \text { et al. } \\
\text { (2012) }\end{array}$ \\
\hline $\begin{array}{l}\text { Trust } \\
\text { TR1 - I believe that PMP providers are trustworthy. } \\
\text { TR2 - I believe that PMP providers offer a secure transaction. } \\
\text { TR3 - I believe that PMP providers keep consumers' interests best in mind. } \\
\text { TR4 - I believe that PMP providers keep their promises and commitments. }\end{array}$ & $\begin{array}{l}\text { Adapted from Pavlou } \\
\text { (2003), and Suh and } \\
\text { Han (2002) }\end{array}$ \\
\hline $\begin{array}{l}\text { Personal Innovativeness (PI) } \\
\text { PI1 - If I find out about new information technology, I seek ways to experience it. } \\
\text { PI2 - Among my peers, I am usually the first to explore new information technologies. } \\
\text { PI3 - I like to experiment with new information technologies. } \\
\text { PI4 - In general, I am very determined to try out new information technologies. }\end{array}$ & $\begin{array}{l}\text { Adopted from } \\
\text { Agarwal and Prasad } \\
\text { (1999), and Yang et } \\
\text { al. (2012) }\end{array}$ \\
\hline Intention to Use PMP (ITU) & Adapted from \\
\hline ITU1 - I intend to use PMP in the next month. & \\
\hline ITU2 - I intend to use PMP in the next 12 months. & (2012) \\
\hline $\begin{array}{l}\text { ITU3 - I will always try to use PMP in my daily life. } \\
\text { ITU4 - I plan to use PMP frequently. }\end{array}$ & \\
\hline
\end{tabular}

The questionnaire was prepared by using Unipark online questionnaire software ${ }^{3}$. The sample of the study consists of 332 participants of which $186(56.0 \%)$ are from Germany and $146(44.0 \%)$ from South Korea ${ }^{4}$. Table 4 shows the demographic profile of the sample. Since the demographic characteristics of the samples show a high degree of equivalence, the sample is expected to be highly comparable (van Herk et al., 2005: 358).

\footnotetext{
${ }^{3}$ The survey was conducted between 19.06.2019-03.07.2019 [The study does not require the approval of the ethics committee]. It was advertised to the Germans and Koreans on Facebook, Instagram, and Reddit. The questionnaire was also distributed by a Korean professor to students and colleagues at Korea University.

${ }^{4}$ The minimum sample size must be ten times the number of arrows directed at a particular construct in a structural model (Hair et al., 2017). Since there are seven structural paths in the reasearch model, the sample size should include at least 70 respondents per country. Out of 402 forms, 50 were incomplete; 18 participants were neither German nor South Korean, and two participants did not own smartphone. Therefore 70 forms were excluded and the sample consisted of 332 participants.
} 
Table 4. Demographic Profile of Respondents

\begin{tabular}{lccc}
\hline $\begin{array}{l}\text { Demographic attribute } \\
\text { Scale }\end{array}$ & $\begin{array}{c}\text { German respondents } \\
(\mathrm{N}=186) \text { count }(\%)\end{array}$ & $\begin{array}{c}\text { S. Korean respondents } \\
(\mathrm{N}=146) \text { count }(\%)\end{array}$ & $\begin{array}{c}\text { All respondents } \\
(\mathrm{N}=332) \text { count }(\%)\end{array}$ \\
\hline $\begin{array}{l}\text { Gender } \\
\text { Male }\end{array}$ & $71(38.2 \%)$ & & \\
Female & $115(61.8 \%)$ & $66(45.2 \%)$ & $137(41.3 \%)$ \\
Age & & $80(54.8 \%)$ & $195(58.7 \%)$ \\
$15-19$ & $3(1.6 \%)$ & $1(0.7 \%)$ & \\
$20-24$ & $67(36.0 \%)$ & $61(41.8 \%)$ & $4(1.2 \%)$ \\
$25-29$ & $80(43.0 \%)$ & $47(32.2 \%)$ & $128(38.6 \%)$ \\
$30-34$ & $17(9.1 \%)$ & $27(18.5 \%)$ & $44(13.3 \%)$ \\
$35-39$ & $6(3.2 \%)$ & $2(1.4 \%)$ & $8(2.4 \%)$ \\
$40-44$ & $2(1.1 \%)$ & $4(2.7 \%)$ & $6(1.8 \%)$ \\
$45-49$ & $2(1.1 \%)$ & $2(1.4 \%)$ & $4(1.2 \%)$ \\
Older than 50 & $9(4.8 \%)$ & $2(1.4 \%)$ & $11(3.3 \%)$ \\
Education & & & \\
No degree & $0(0.0 \%)$ & $0(0.0 \%)$ & $0(0.0 \%)$ \\
Junior school degree & $2(1.1 \%)$ & $0(0.0 \%)$ & $2(0.6 \%)$ \\
Junior high school degree & $5(2.7 \%)$ & $2(1.4 \%)$ & $7(2.1 \%)$ \\
High school degree & $50(26.9 \%)$ & $54(37.0 \%)$ & $104(31.3 \%)$ \\
Vocational training & $11(5.9 \%)$ & $2(1.4 \%)$ & $13(3.9 \%)$ \\
Bachelor's degree & $72(38.7 \%)$ & $64(43.8 \%)$ & $136(41.0 \%)$ \\
Master's degree & $41(22.0 \%)$ & $21(14.4 \%)$ & $62(18.7 \%)$ \\
Promotion & $5(2.7 \%)$ & $3(2.1 \%)$ & $8(2.4 \%)$ \\
PMP usage & & & \\
Never used & $122(65.6 \%)$ & $45(30.8 \%)$ & $167(50.3 \%)$ \\
Tried once & $15(8.1 \%)$ & $9(6.2 \%)$ & $24(7.2 \%)$ \\
Less than once per month & $12(6.5 \%)$ & $12(8.2 \%)$ & $24(7.2 \%)$ \\
1 - 3 times per month & $9(4.8 \%)$ & $22(15.1 \%)$ & $31(9.3 \%)$ \\
Once a week & $8(4.3 \%)$ & $13(8.9 \%)$ & $21(6.3 \%)$ \\
2 - 3 times a week & $20(10.7 \%)$ & $45(30.8 \%)$ & $65(19.6 \%)$ \\
\hline
\end{tabular}

\subsection{Analysis}

The method of Partial Least Squares (PLS) ${ }^{5}$ was used to test the research hypotheses. A three-step approach was followed using SmartPLS 3 software and IBM SPSS Statistics 26.0. The first step was to evaluate the reliability and validity of the measurement model (outer model), which includes the latent factors and items. Since the determinants are measured reflectively, the factor loadings of the items were first checked. Cronbach's alpha, as well as the composite reliability (CR) were assessed to determine the internal consistency of the formed determinants. Convergent and discriminant validity were tested by estimating the average variance extracted (AVE) and the Fornell-Larcker criterion. In the second step, the relationships between the independent and dependent variable within the structural model (inner model) were estimated with PLS. In this phase, as suggested by Hair et al. (2014: 113), the robustness and significance of the model were determined by checking the coefficient of determination $\left(\mathrm{R}^{2}\right)$, the effect size $\left(\mathrm{f}^{2}\right)$, and the path coefficients. Lastly, a multigroup analysis (MGA) was used to investigate to determine significant differences in the path coefficients between the two samples.

\footnotetext{
${ }^{5}$ PLS is a technique used to model latent structural equations. The technique is based on path analysis and has become established in various fields of research as a method for multivariate assessments. The advantage of using the PLS in a structural equation model (SEM) is that even with a small sample size a high statistical significance can be achieved, as long as the minimum criterion of 10 participants per structural path is met. PLS is also advantageous, when data have been collected that are not subject to multivariate normal distribution ( Hair et al., 2014: 106, 108; Hair et al., 2019: 5).
} 


\section{Findings}

\subsection{Reliability and Validity}

The reliability and validity examination of the measurement model are depicted in Table 5. In the course of assessing the reliability, initially, the item reliability was determined using factor loadings ${ }^{6}$. In the German sample, all factor loadings exceed the limit of 0.707 and no adjustments had to be made. Here, the latent factors adequately explain the observed items. Conversely, in the South Korean sample, the threshold was not reached by the items PR4, PEU4, and TR3, therefore they were removed from the model. To evaluate the reliability of internal consistency, Cronbach's alpha and CR were used as a measure. Since the threshold of 0.7 is exceeded by both the German $(0.820$ to $0.965)$ and the South Korean sample (0.762 to 0.936), this indicates a satisfactory internal consistency. To further verify the internal reliability of reflective items, the CR was also calculated. With respect to both samples, all latent factors meet the conditions for CR, since the German (0.882 to 0.975$)$ and the South Korean sample (0.862 to 0.960$)$ reach the threshold. The validity of the latent factors is subsequently determined by checking for the convergent and discriminant validity. To test the convergent validity of the eight constructs, the $\mathrm{AVE}^{7}$ was used. Both German (0.709 to 0.906) and South Korean sample (0.678 to 0.922) have an AVE greater than 0.5 (Fornell and Larcker (1981: 46), therefore the convergent validity was confirmed.

\footnotetext{
${ }^{6}$ Factor loadings of all items are measured to ascertain how high the respective latent factor loads on the individual items. If the factor loading exceeds the limit value of 0.707 , it is ensured that the corresponding determinant explains more than half of the items variance and hence the item can be deemed reliable (Fornell and Larcker, 1981: 43; Hair et al., 2011: $145)$.

${ }^{7}$ The value of the AVE reveals how much variance the aggregated construct can explain for its respective items (Hair et al., 2014: 111).
} 
Table 5. Reliability and validity results

\begin{tabular}{|c|c|c|c|c|c|c|c|c|}
\hline \multirow{2}{*}{$\begin{array}{l}\text { Construct } \\
\text { Item }\end{array}$} & \multicolumn{2}{|c|}{ Item loading } & \multicolumn{2}{|c|}{ Cronbach's alpha } & \multicolumn{2}{|c|}{ CR } & \multicolumn{2}{|c|}{ AVE } \\
\hline & Germany & S. Korea & Germany & S. Korea & Germany & S. Korea & Germany & S. Korea \\
\hline \multicolumn{3}{|c|}{ Perceived Usefulness (PU) } & 0.909 & 0.849 & 0.935 & 0.895 & 0.784 & 0.682 \\
\hline PU1 & 0.860 & 0.742 & & & & & & \\
\hline PU2 & 0.897 & 0.829 & & & & & & \\
\hline PU3 & 0.915 & 0.880 & & & & & & \\
\hline PU4 & 0.868 & 0.845 & & & & & & \\
\hline \multicolumn{3}{|c|}{ Perceived Risk (PR) } & 0.862 & 0.762 & 0.907 & 0.862 & 0.709 & 0.678 \\
\hline PR1 & 0.878 & 0.820 & & & & & & \\
\hline PR2 & 0.825 & 0.743 & & & & & & \\
\hline PR3 & 0.904 & 0.889 & & & & & & \\
\hline PR4 & 0.753 & $0.331^{\mathrm{a}}$ & & & & & & \\
\hline \multicolumn{3}{|c|}{ Perceived Ease of Use (PEU) } & 0.820 & 0.916 & 0.882 & 0.960 & 0.653 & 0.922 \\
\hline PEU1 & 0.710 & 0.914 & & & & & & \\
\hline PEU2 & 0.831 & 0.911 & & & & & & \\
\hline PEU3 & 0.889 & 0.873 & & & & & & \\
\hline PEU4 & 0.791 & $0.675^{\mathrm{a}}$ & & & & & & \\
\hline \multicolumn{3}{|c|}{ Perceived Compatibility (PC) } & 0.913 & 0.915 & 0.945 & 0.946 & 0.852 & 0.855 \\
\hline PC1 & 0.930 & 0.942 & & & & & & \\
\hline PC2 & 0.938 & 0.943 & & & & & & \\
\hline PC3 & 0.902 & 0.887 & & & & & & \\
\hline \multicolumn{3}{|c|}{ Social Influence (SI) } & 0.941 & 0.936 & 0.962 & 0.959 & 0.895 & 0.886 \\
\hline SI1 & 0.953 & 0.931 & & & & & & \\
\hline SI2 & 0.934 & 0.959 & & & & & & \\
\hline SI3 & 0.951 & 0.934 & & & & & & \\
\hline \multicolumn{3}{|l|}{ Trust } & 0.865 & 0.845 & 0.908 & 0.906 & 0.712 & 0.763 \\
\hline TR1 & 0.873 & 0.881 & & & & & & \\
\hline TR2 & 0.880 & 0.850 & & & & & & \\
\hline TR3 & 0.742 & $0.508^{\mathrm{a}}$ & & & & & & \\
\hline TR4 & 0.872 & 0.861 & & & & & & \\
\hline \multicolumn{3}{|c|}{ Personal Innovativeness (PI) } & 0.923 & 0.924 & 0.945 & 0.946 & 0.812 & 0.814 \\
\hline PI1 & 0.863 & 0.916 & & & & & & \\
\hline PI2 & 0.909 & 0.870 & & & & & & \\
\hline PI3 & 0.931 & 0.905 & & & & & & \\
\hline PI4 & 0.900 & 0.917 & & & & & & \\
\hline \multicolumn{3}{|c|}{ Intention to Use PMP (ITU) } & 0.965 & 0.928 & 0.975 & 0.949 & 0.906 & 0.822 \\
\hline ITU1 & 0.952 & 0.924 & & & & & & \\
\hline ITU2 & 0.939 & 0.931 & & & & & & \\
\hline ITU3 & 0.951 & 0.870 & & & & & & \\
\hline ITU4 & 0.965 & 0.901 & & & & & & \\
\hline
\end{tabular}

Note: ${ }^{\text {a }}=$ Item deleted from model and further analysis because of low factor loading.

Table 6 shows discriminant validity ${ }^{8}$ results. The diagonal row shows the square rooted AVE values in bold, with the correlations below them. The discriminant validity has been confirmed for the German sample, as the diagonal values are higher than the correlations beneath them. Contrary to this, the first test in the Korean sample showed that the value of the correlation between the constructs PEU and PC is higher than the square root of the AVE of PEU. In response, the affected item PEU3 was deleted from the model, whereafter, the discriminant validity subsequently reached a satisfactory level. In the end, the measurement model met all established requirements.

\footnotetext{
${ }^{8}$ Discriminant validity (DV) represents the extent to which a latent factor differs from others and, accordingly, whether it measures what it is supposed to measure (Hair et al., 2014: 112). The Fornell-Larcker criterion was applied to test DV, which compares the square root of the AVE with the value of the correlation between two constructs. The discriminant variance is judged to be appropriate as soon as the square root of the respective AVE is greater than the correlations between the constructs (Fornell and Larcker, 1981: 46).
} 
Table 6. Discriminant Validity - German Sample

\begin{tabular}{|c|c|c|c|c|c|c|c|c|}
\hline Construct & PU & $\mathbf{P R}$ & PEU & PC & SI & TR & PI & ITU \\
\hline PU & 0.885 & & & & & & & \\
\hline PR & -0.436 & 0.842 & & & & & & \\
\hline PEU & 0.341 & -0.418 & 0.808 & & & & & \\
\hline PC & 0.701 & -0.508 & 0.491 & 0.923 & & & & \\
\hline SI & 0.448 & -0.349 & 0.209 & 0.395 & 0.946 & & & \\
\hline TR & 0.507 & -0.666 & 0.546 & 0.622 & 0.413 & 0.844 & & \\
\hline PI & 0.517 & -0.458 & 0.393 & 0.562 & 0.322 & 0.369 & 0.901 & \\
\hline ITU & 0.735 & -0.607 & 0.389 & 0.722 & 0.527 & 0.605 & 0.630 & 0.952 \\
\hline \multicolumn{9}{|c|}{ Discriminant validity - South Korean sample } \\
\hline Construct & PU & PR & PEU & PC & SI & TR & PI & ITU \\
\hline PU & 0.826 & & & & & & & \\
\hline PR & -0.291 & 0.823 & & & & & & \\
\hline PEU & 0.801 & -0.363 & 0.960 & & & & & \\
\hline PC & 0.768 & -0.324 & 0.900 & 0.924 & & & & \\
\hline SI & 0.497 & -0.212 & 0.573 & 0.502 & 0.941 & & & \\
\hline TR & 0.456 & -0.503 & 0.498 & 0.510 & 0.356 & 0.874 & & \\
\hline PI & 0.456 & -0.281 & 0.495 & 0.456 & 0.416 & 0.350 & 0.902 & \\
\hline ITU & 0.706 & -0.513 & 0.762 & 0.790 & 0.465 & 0.511 & 0.556 & 0.907 \\
\hline
\end{tabular}

Lastly, mean values of the variables are in Table 7. The means of the German sample fall within the range of 3.217 (SI) and 5.738 (PEU), while the Korean sample lies between 2.963 (PR) and 5.128 (ITU).

Table 7. Means and Standard Deviations of the Variables

\begin{tabular}{lcccccccc}
\hline \multirow{2}{*}{$\begin{array}{l}\text { Construct } \\
\text { Mean }\end{array}$} & \multicolumn{2}{c}{ SD } & \multicolumn{2}{c}{ 25th percentile } & \multicolumn{2}{c}{ 75th percentile } \\
& Germany & S. Korea & Germany & S. Korea & Germany & S. Korea & Germany & S. Korea \\
\hline Perceived Usefulness (PU) & 4.866 & 5.014 & 1.456 & 1.375 & 4.000 & 4.000 & 6.000 & 6.000 \\
Perceived Risk (PR) & 4.133 & 2.963 & 1.400 & 1.207 & 3.000 & 2.000 & 5.250 & 3.667 \\
Perceived Ease of Use (PEU) & 5.738 & 4.874 & 0.950 & 1.642 & 5.250 & 4.000 & 6.500 & 6.000 \\
Perceived Compatibility (PC) & 4.862 & 5.094 & 1.612 & 1.636 & 3.667 & 4.000 & 6.000 & 6.333 \\
Social Influence (SI) & 3.217 & 3.671 & 1.613 & 1.670 & 2.000 & 2.333 & 4.000 & 5.000 \\
Trust & 4.566 & 4.550 & 1.193 & 1.185 & 3.938 & 3.667 & 5.500 & 5.333 \\
Personal Innovativeness (PI) & 4.140 & 4.569 & 1.545 & 1.540 & 3.000 & 3.250 & 5.250 & 5.813 \\
Intention to Use PMP (ITU) & 3.785 & 5.128 & 2.064 & 1.628 & 2.000 & 4.250 & 5.750 & 6.500 \\
\hline
\end{tabular}

\subsection{Hypotheses Testing}

The structural model is analyzed by applying the PLS method (Figure 2 and Figure 3). While the German structural model shows a coefficient of determination $\left(\mathrm{R}^{2}\right)$ of 0.731 , the South Korean model shows a value of 0.741 . Following the classification of Chin (1998: 323), both structural models exceed the threshold value of 0.67 therefore have a strong explanatory power. To better assess the quality of the model, another method is to determine the effect size $f^{2}$ for each path between an independent and dependent variable ${ }^{9}$. In the case of calculating the $\mathrm{f}^{2}$ value for the German sample, PU has a medium effect on ITU. Besides, PR, PC, SI as well as PI show a small effect strength towards ITU. In South Korean sample, PU and PI show a small effect on ITU, while PR and PC show a medium effect on ITU.

\footnotetext{
${ }^{9}$ The effect size is determined by calculating the coefficient of determination $\mathrm{R}^{2}$ for one path model after eliminating a certain independent variable, and a second path model for the complete model. Then the change in the $\mathrm{R}^{2}$ value caused by the omission of the independent variable can be calculated, which corresponds to the effect size $\mathrm{f}^{2}$ (Hair et al., 2014: 114). According to Cohen (1988: 477f.), $\mathrm{f}^{2}$ values of $0.02,0.15$, and 0.35 can be interpreted as the lower threshold for small, medium, and large effect sizes.
} 


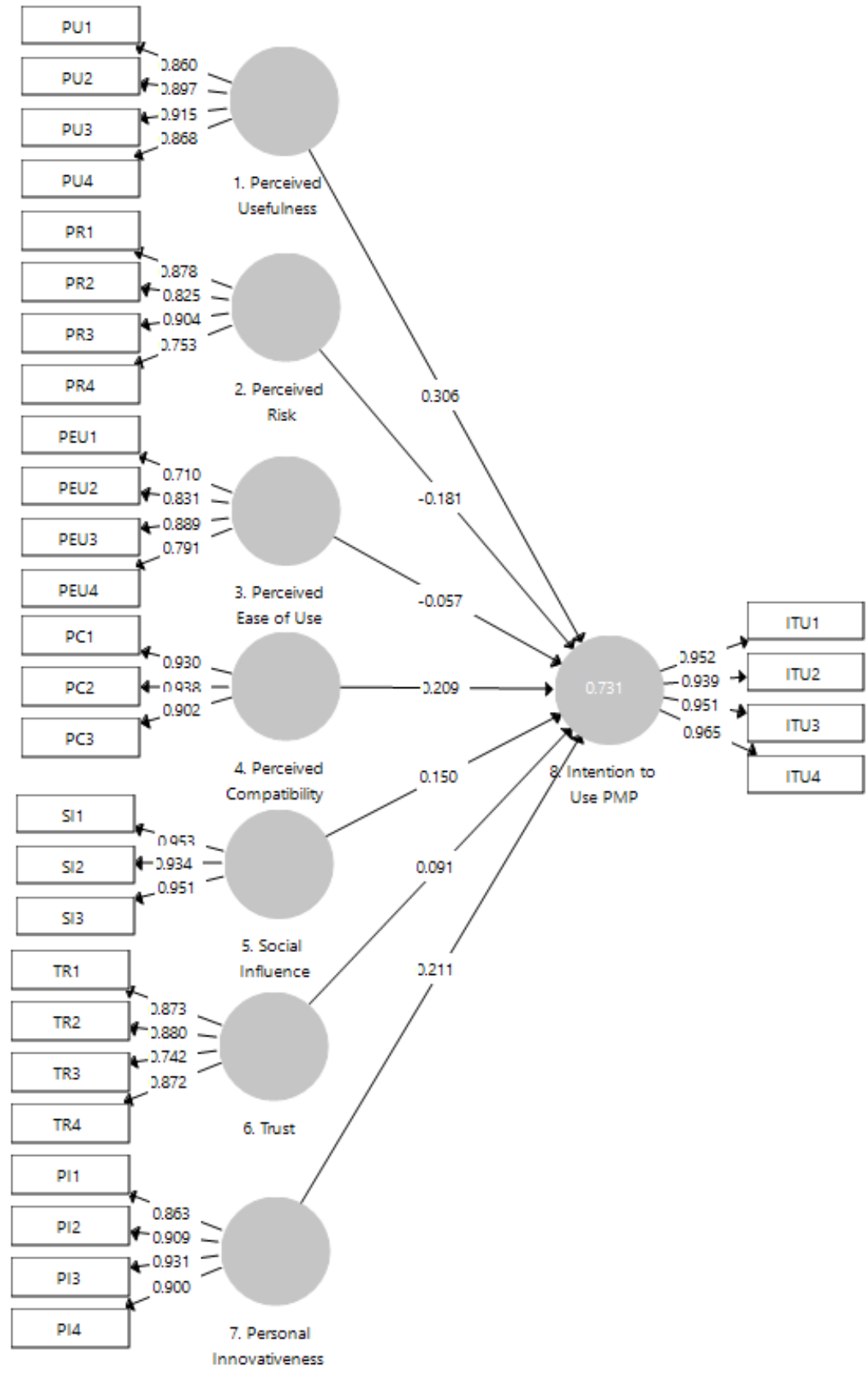

Figure 2. Structural model of German sample 


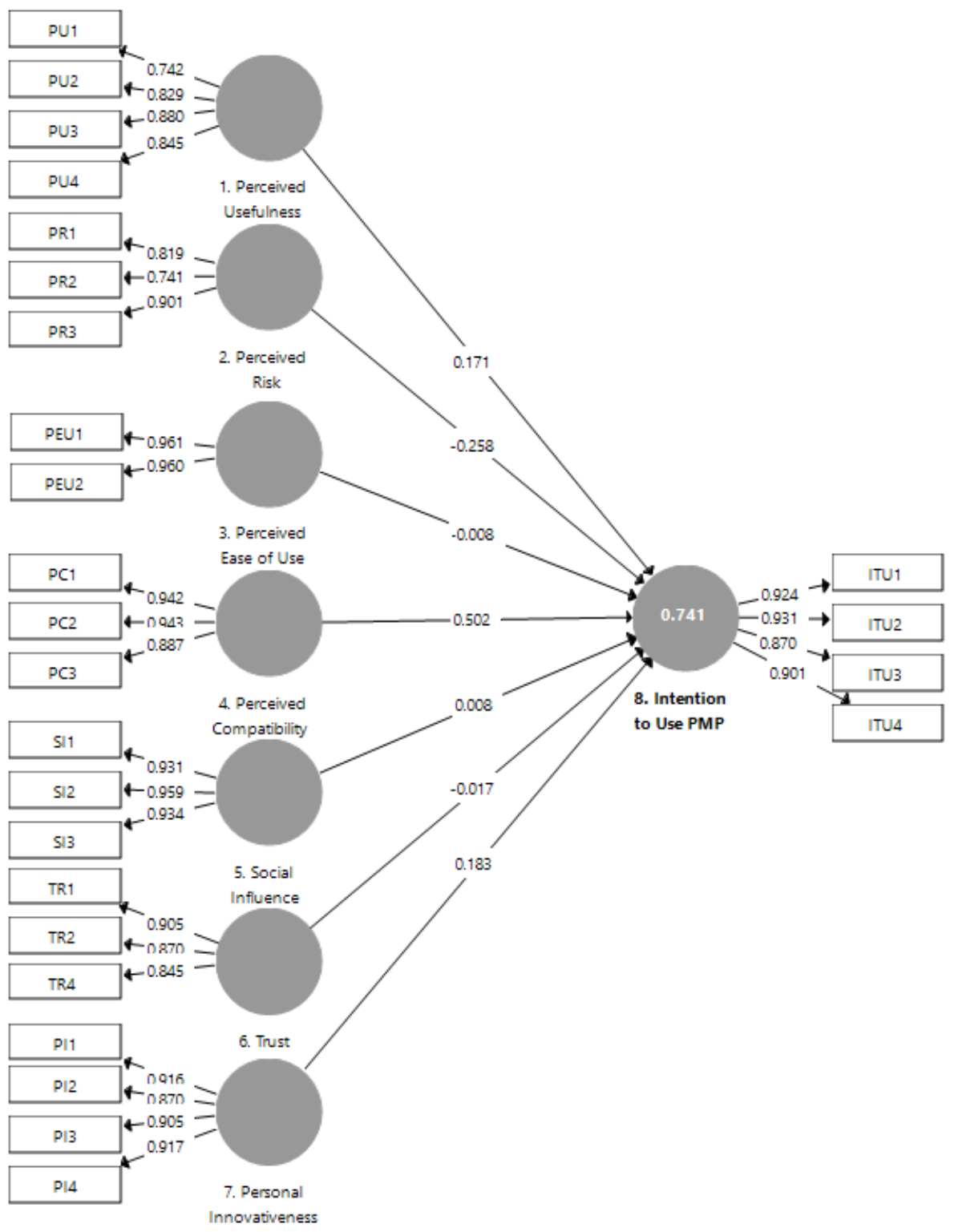

Figure 3. Structural model of Korean sample

Table 8 displays the results of the path model analysis using bootstrapping ${ }^{10}$ procedure. The evaluation of the path model analysis of the German sample indicates that the effects of PU $\left(\mathrm{H}_{1 \mathrm{a}}\right), \mathrm{PC}$ $\left(\mathrm{H}_{4 \mathrm{a}}\right)$, SI $\left(\mathrm{H}_{5 \mathrm{a}}\right)$, and PI $\left(\mathrm{H}_{7 \mathrm{a}}\right)$ on ITU are significant at a level of $\mathrm{p}<0.001$. Furthermore, PR's path $\left(\mathrm{H}_{2 \mathrm{a}}\right)$ is also significant, but at a slightly lower level of $p<0.01$. No significant effect on the dependent variable ITU was proven for the two determinants PEU $\left(\mathrm{H}_{3 \mathrm{a}}\right)$ and trust $\left(\mathrm{H}_{6 \mathrm{a}}\right)$. In total, five of seven hypotheses were confirmed in the German sample. The Korean sample shows that the effects of PU $\left(\mathrm{H}_{1 b}\right), P R\left(\mathrm{H}_{2 b}\right), P C\left(\mathrm{H}_{4 b}\right)$ and PI $\left(\mathrm{H}_{7 b}\right)$ on ITU are significant at a level of $\mathrm{p}<0.001$. No statistically significant effect on the dependent variable was found for the variables PEU $\left(\mathrm{H}_{3 b}\right)$, SI $\left(\mathrm{H}_{5 b}\right)$, and trust $\left(\mathrm{H}_{6 \mathrm{~b}}\right)$. In total, four out of seven hypotheses were confirmed in the South Korean sample.

\footnotetext{
${ }^{10}$ Bootstrapping is a method of resampling, where repetitive samples are taken from the data in order to estimate the significance of the path coefficients (Streukens and Leroi-Werelds, 2016: 619). In the absence of distributional assumptions, parametric significance tests can normally not be performed when using the PLS method (Weiber and Mühlhaus, 2014: 327). However, since t-values are calculated by applying the bootstrapping procedure, this method is well suited (Efron, 1979: 1). Bootstrapping was performed with 10,000 bootstrap samples as it is suggested in Streukens and Leroi-Werelds's study (2016: 625). Through this procedure, path coefficients and parameters for estimating significance are generated.
} 
Table 8. Path Modeling Results - German Sample

\begin{tabular}{lccccc}
\hline Hypothesis & Path coefficient & t-value & p-value & $\mathbf{f}^{\mathbf{2}}$ & Support \\
\hline H1a. PU > ITU & 0.306 & 5.913 & $0.000^{* * *}$ & 0.157 & Yes \\
H2a. PR > ITU & -0.181 & 2.752 & $0.003^{* *}$ & 0.061 & Yes \\
H3a. PEU > ITU & -0.057 & 1.097 & $0.136^{\text {n.s. }}$ & 0.008 & No \\
H4a. PC > ITU & 0.209 & 3.597 & $0.000^{* * *}$ & 0.060 & Yes \\
H5a. SI > ITU & 0.150 & 3.570 & $0.000^{* * *}$ & 0.062 & Yes \\
H6a. Trust $>$ ITU & 0.091 & 1.324 & $0.093^{\text {n.s. }}$ & 0.012 & No \\
H7a. PI > ITU & 0.211 & 4.672 & $0.000^{* * *}$ & 0.098 & Yes \\
\hline & Path modeling results - South Korean sample & & Support \\
\hline Hypothesis & Path coefficient & t-value & p-value & $\mathbf{f}^{\mathbf{2}}$ & Yes \\
\hline H1b. PU > ITU & 0.171 & 2.446 & $0.007^{* *}$ & 0.038 & Yes \\
H2b. PR > ITU & -0.258 & 4.038 & $0.000^{* * *}$ & 0.185 & No \\
H3b. PEU > ITU & -0.008 & 0.056 & $0.478^{\text {n.s. }}$ & 0.000 & Yes \\
H4b. PC > ITU & 0.502 & 3.742 & $0.000^{* * *}$ & 0.174 & No \\
H5b. SI $>$ ITU & 0.008 & 0.139 & $0.445^{\text {n.s. }}$ & 0.000 & No \\
H6b. Trust $>$ ITU & -0.017 & 0.291 & $0.386^{\text {n.s. }}$ & 0.001 & Yes \\
H7b. PI > ITU & 0.183 & 3.069 & $0.001^{* *}$ & 0.091 & \\
\hline Note:
\end{tabular}

Note: n.s. $=$ not significant; $*=\mathrm{p}<0.05 ; * *=\mathrm{p}<0.01 ; * * *=\mathrm{p}<0.001$.

Lastly, the $\mathrm{MGA}^{11}$ was performed to discover significant differences in path coefficients between the German and South Korean samples. The results are shown in Table 9.

Table 9. Multigroup Analysis

\begin{tabular}{|c|c|c|c|c|c|}
\hline \multirow{2}{*}{ Hypothesis } & \multicolumn{2}{|c|}{ Path coefficient } & \multirow{2}{*}{$\begin{array}{l}\text { Path coefficient difference } \\
\text { Germany - South Korea }\end{array}$} & \multirow{2}{*}{ p-value } & \multirow{2}{*}{ Support } \\
\hline & Germany & South Korea & & & \\
\hline H1c. $P U>$ ITU & $0.304 * * *$ & $0.186^{* *}$ & 0.118 & $0.095^{\text {n.s. }}$ & No \\
\hline H2c. PR > ITU & $-0.200 * *$ & $-0.270 * * *$ & 0.070 & $0.216^{\text {n.s. }}$ & No \\
\hline H3c. PEU > ITU & $-0.063^{\text {n.s. }}$ & $-0.074^{\text {n.s. }}$ & 0.011 & $0.461^{\text {n.s. }}$ & No \\
\hline H4c. PC > ITU & $0.194 * * *$ & $0.529 * * *$ & -0.335 & $0.016^{*}$ & Yes \\
\hline H5c. SI > ITU & $0.157 * * *$ & $0.041^{\text {n.s. }}$ & 0.117 & $0.049 *$ & No \\
\hline H6c. Trust $>$ ITU & $0.081^{\text {n.s. }}$ & $-0.022^{\text {n.s. }}$ & 0.103 & $0.117^{\text {n.s. }}$ & No \\
\hline H7c. PI > ITU & $0.211 * * *$ & $0.193 * * *$ & 0.018 & $0.406^{\text {n.s. }}$ & No \\
\hline
\end{tabular}

Note: n.s. $=$ not significant; $*=p<0.05 ; * *=p<0.01 ; * * *=p<0.001$.

The first significant group difference arises in the effect of PC and ITU. As expected in hypothesis $\mathrm{H}_{4 \mathrm{c}}$, the influence of PC is stronger in South Korea, by which the ITU is positively influenced much more than in Germany. A further significant difference is apparent in the effect of SI on ITU. Surprisingly, the path coefficient of the German sample is higher than the Korean sample. Contrary to what was expected in hypothesis $\mathrm{H}_{5 \mathrm{c}}$, the $\mathrm{SI}$ is stronger in Germany, and the ITU is less positively influenced by SI in South Korea. It should be noted that the SI path coefficient of the South Korean sample is also insignificant.

\footnotetext{
11 As deriving conclusions on the basis of path coefficients alone leads to misinterpretations (Rodríguez-Entrena et al., 2018), it was first examined whether it is possible to test the two samples with an MGA. For this purpose, it was necessary to check whether the measurement invariance is fulfilled. This can be validated by testing the configural as well as the compositional invariance. The configural invariance is confirmed as soon as the research model meets certain qualitative requirements. The requirements include, for instance, the uniform handling of data (e.g., coding) and whether the countryspecific samples use the same items (Henseler et al., 2016: 409, 413). To verify the compositional invariance, the permutation method is used, which examines whether constructs and items are formed identically across both samples (Sarstedt et al., 2017: 210). If the p-values generated by this procedure are above 0.05 and below 0.95 , the compositional invariance is fulfilled (Hair et al., 2018: 164). The configural invariance is fulfilled by the research model of this study. The compositional invariance is also confirmed since the permutation p-values are within the interval. Based on the successful testing of the measurement invariance, the comparability of the measurement models of the two country samples is possible (see Henseler et al., 2016: 423).
} 


\section{Conclusion}

The aim of this study was to analyze the acceptance factors of PMP and to determine the constitutive factors that influence the individuals' intention to use PMP in Germany and in South Korea, and to compare the strengths of the effects of the variables on intention in order to detect differences between these countries. The model developed based on literature review showed a strong predictive power of $73.1 \%$ for the German and $74.1 \%$ for the South Korean sample. The predictive power is considerably stronger compared to research models in the literature with a similar thematic focus i.e., MP at the PoS- (e.g., Kerviler et al., 2016; Handarkho and Harjoseputro, 2020).

Results show that PU has a significantly positive influence on the PMP use intention in both Germany and South Korea. This finding is consistent with findings from Germany (Martens et al., 2017) and South Korea (Kim et al., 2010; Lee, 2019). A special emphasis should be placed on the PU particularly in Germany, as it had the most decisive influence among all significant determinants in this sample, which is again consistent with previous studies (e.g., Nyaboga et al., 2015; Slade et al., 2015). The MGA has shown that there is no significant difference between the two samples. Contrary to the findings of Sun and Zhang (2006), the absence of differences may stem from the fact that people-despite cultural differences- perceive the merits of the technology similarly. On the other hand, PR has a significantly negative influence on the intention to use PMP in both Germany and South Korea. While the inhibitory effect of PR on the intention to use PMP has already been established in several PMP studies (e.g., Slade et al., 2015; Kerviler et al., 2016), the empirical investigation by Handarkho and Harjoseputro (2020) could not prove a significant effect. The results of Lee (2019) underpin the significantly negative influence of the PR on the intention in South Korea. Although the two countries diverge strongly in the extent of uncertainty avoidance, in the comparison between the two samples - unlike hypothesized- no significant difference was found.

It was assumed that the PEU influences the behavioral intention, neither in Germany nor in South Korea a significant positive effect could be confirmed. Martens et al. (2017) in Germany and Shin and Lee (2014) in South Korea also did not find a significant effect of the PEU on intention. The result is also consistent with Slade et al.'s study (2015). In contrast, Nyaboga et al. (2015) found a significant effect of the PEU on PMP use intention. Likewise, the MGA could not demonstrate significant differences between the two samples. Although Straub et al. (1997) and Im et al. (2011) emphasize that the PEU influences nations with a predominant individualistic culture more strongly, the reason of the mentioned finding may be because a large proportion of the respondents have not yet used PMP, which makes it difficult to assess its ease of use. The findings could also be due to sampling issues since the samples contain mostly younger people. These people have often grown up with mobile devices and are often both more proficient and skilled with them, which is why the PEU plays a secondary role for them. Another result of the study is that PC both in German and South Korean sample had a significantly positive influence on the intention to use PMP. The importance of the factor is particularly noteworthy in South Korea, as the PC has the strongest influence on the behavioral intention among all seven determinants. The results are also consistent with the study of Ramos-de-Luna et al. (2016). On the other hand, the significantly positive effect of PC on the intention to use in Germany has already been validated by Schierz et al. (2010) and is in line with the result obtained here. Furthermore, it was hypothesized that due to the lower power distance and predominant individuality in Germany, PC is less prevalent than in South Korea; the influence of PC on the intention to us PMP was found stronger in South Korea than in Germany.

Results also showed that SI has a significant positive effect in the German sample. However, the study did not find a significant influence of the SI in the South Korean sample. While the significance with regard to the German sample is consistent with much of the research (e.g., LiébanaCabanillas et al., 2015b; Slade et al., 2015; Bailey et al., 2020; Finken and Heiduk, 2021), it is not in line with the results of Handarkho and Harjoseputro (2020) as well as Teo et al. (2015) -thus the situation is exactly the opposite for the Korean sample. A further look at the results of empirical MP 
research reveals this divergence in South Korea as well. While Lee (2019) indicated a significant influence of the SI on the MP use intention, Shin (2009) revealed that the relationship is insignificant. The MGA also highlights that there is a significant difference between Germany and South Korea with respect to the influence of the SI on the intention to use PMP. Contrary to the hypothesis, the influence of the SI found stronger in Germany than in South Korea. The assumption is that Germans are more likely to be influenced by their social environment than South Koreans in regard to the use of PMP. This result is very surprising as it was initially expected that the effect would be stronger in South Korea since it is a very collectivist country. The PMP adoption rate may explain this deviation since the rate is certainly higher in South Korea than in Germany. Thus, Koreans may not value the advice of people on the matter from the social milieu as highly as Germans do.

Trust did not show a significant effect on the intention to use PMP in neither Germany nor South Korea and fails to match the hypothesized effect. Consequently, these results also diverge with other PMP studies that include trust as a significant driver in their research (e.g., Slade et al., 2015; Bailey et al., 2020). These results also deviate from the findings of Shin (2009), who demonstrated a significant effect of trust on MP use intention in South Korea. The MGA also failed to reveal a significant difference between the two samples. Hence, the results of the research by Xin et al. (2015), who found a significant difference in the influence of trust on MP intention to use, based on cultural factors, could not be replicated. Overall, the results imply that trust does not affect the intention to use in either of the two countries. Two potential reasons can be addressed. Firstly, the insignificance could be attributable to the lack of awareness on the part of individuals about the extent to which their data are processed and used. Secondly, it may be unclear to individuals who are the actual providers of the PMP services and who should therefore be trusted. At last, both German and South Korean sample confirmed that PI is a significant positive driver of the intention to use PMP, with the effect being marginally stronger in Germany. These results correspond to previous studies (e.g., LiébanaCabanillas et al., 2015b; Handarkho and Harjoseputro, 2020; Finkend and Heiduk, 2021). The comparative analysis showed no significant difference between the two samples. To draw an inference based on the varying strength of the two significant results is difficult, however it can be concluded that the result demonstrates nationality and/or the cultural context does not affect the influence of the PI on the intention to use PMP. Individuals with a high affinity for innovative technologies are more likely to try new technology. Therefore, the positive significance could be stemmed from the high eagerness of individuals with a high level of the PI to experiment and experience new information technologies.

In summary, the research model is robust and is supported by a multitude of significant results. The empirical evaluation showed that in Germany, the PU is the driver that influences the intention to use PMP most, followed by the PI, PC, and SI. Conversely, the analysis in South Korea showed that the PC is the driver with the most substantial impact, while the PI and PU also have an effect on the behavioral intention. In both countries, the PR manifested itself as an inhibitor of PMP use intention. In total, the results supported nine out of fourteen hypotheses. The MGA, with its ability to uncover cross-sample discrepancies, revealed significant differences between the two countries only for the determinants PC and SI.

\section{Discussion}

Global payment systems are advancing rapidly. Innovative tech companies are interfering with the business of long-established payment service providers and banks. However, the development of MP services alone is not enough since, in addition to the acceptability at merchants' payment terminals, the subsequent adoption of a large number of consumers is also necessary. Although MP at the PoS has experienced increased usage in recent years, it is still far from the usage rate desired by MP providers. To further promote the diffusion of PMP, it is of particular importance for managers of 
MP services and merchants, who support MP solutions, to better understand the factors that drive and inhibit consumers to use them.

The first implication for managers was derived based on the findings with respect to the positive driver PU. These findings imply the importance of communicating the benefits of PMP to individuals, e.g., the increased speed of the payment process and the payment convenience. Hence, PMP providers and retailers in Germany as well as South Korea need to develop business strategies that are designed to make individuals aware of the usefulness of PMP services with marketing campaigns emphasizing the speed and convenience, offering vouchers, providing refunds through a cashback system or gamification. Second, regarding PR, security aspects should be communicated to consumers to a greater extent. Providers of PMP services or merchants could develop communication strategies to clearly express the high-security mechanisms to consumers and raise consciousness of payment security to alleviate security and data protection concerns. Third, the results of PC implies that PMP service providers should make sure that potential and existing users perceive the greatest possible compatibility of the application, as this increases the use intention. Companies need to develop marketing messages to ensure consumers that PMP is compatible with existing payment methods. However, the results also provide an indication that the positive perception of PC in South Korea has a much stronger effect on the intention to use PMP than in Germany. Therefore, the actors may need to develop different approaches for the countries regarding PC. Fourth, the findings have shown that opinions from their social environment influence German individuals. Managers of PMP services, as well as retailers, should, therefore, take into account the importance of the social surroundings of consumers when formulating strategies for the German market. Fifth, the innovative ability of individuals has a driving effect regarding the intention to use PMP. In connection with this driver, retailers, as well as providers of PMP services, can launch various initiatives so that the innovative curiosity of consumers is more met and satisfied. Developers of PMP services can involve consumers for example in the conception of the service. Early public testing could be considered as another way of involving people in the discovery of innovations. These two initiatives can contribute to improving the product and can also help to build up an initial support base, which may also have a social impact on other innovators. Another strategy that managers of PMP services, as well as retailers, may consider is to implement marketing campaigns with a special focus on individuals with a high affinity for novelties. Campaigns can also highlight the innovative features of the services. Sixth, the factors PEU and trust, interestingly, did not show a significant influence on the intention to use PMP. Given that some participants in the survey had never used PMP services before, these results indicate that they might have had little experience in using PMP. This is evident in the PEU factor, as non-users may not be aware of the ease and configuration of the application. On the other hand, the insignificance of the factor trust hints at a general unawareness of the different service providers standing behind the PMP services. Ultimately, the lack of significance of the PEU and trust does not allow for unambiguous implications to be inferred. Independent of that, managers of PMP services can still consider some points concerning the two factors in their business strategies. In the context of the PEU, PMP service executives should always strive to provide a simple application that is convenient and of low complexity. Also, the application should be continuously developed further, as long as there are new technologies such as face recognition, for example, that can be implemented in this regard in a user-facilitating manner. This ensures that the application remains at the cutting edge of technology and that its competitive advantage is continuously being expanded. In view of the trust placed in them, PMP providers should also provide a high degree of transparency about their processes to individuals.

\section{Limitations and Suggestions for Further Research}

The convenient sampling method made it impossible to generalize the results to the population. Both the German (79.0\%) and the South Korean sample (74.0\%) have a large overlap of young participants 
between 20 and 29 years of age. Specifically, between generations, some differences in acceptance factors can be expected. To obtain a more heterogeneous sample in future studies, care should be taken during data collection to ensure that the demographic facets correspond to the respective target population. This would lead to better generalizability of the PMP acceptance factors onto the population, together with a random sampling procedure.

Second, the samples were drawn from two specific countries, therefore the results cannot be inferred on other countries. While only two significant differences in the factors of PMP use intention were found between Germany and South Korea, even stronger discrepancies between other countries might arise. Especially between countries that differ to an even greater extent, for example, in economic or technological terms. It is therefore recommended that further studies should be replicated and conducted in other countries, so that the PMP acceptance factors in conjunction with cultural differences can be validated.

Third, the research model developed and validated in this study is limited to seven most relevant factors regarding the intention to use PMP based on a systematic literature review. Although the proposed model showed a strong predictive power, there is still a possibility that other important factors would have a significant impact on the acceptance of PMP. It must be noted that the results are only of static nature. Especially since factors such as the PR, PEU, or trust can change significantly during the acceptance process of technology, it is not possible to draw conclusions about the future. The PMP service can develop further over time, and aspects such as usefulness or security can likewise change. To measure this dynamic process over a more extended period, future studies can focus on longitudinal studies.

There are some contributions of this paper to the existing MP/PMP literature. This study is one of the first empirical studies in Germany to investigate acceptance factors of the PMP. So far, only Schierz et al. (2010) and Martens et al. (2017) had researched the determinants of acceptance of MP, and in a recent study Finken and Heiduk (2021) analyzed the factors affecting the adoption of PMP, but with a specific focus on Apple Pay. From a Korean perspective, this study also contributes to the existing PMP literature. Therefore, the study could be a basis for researchers who want to make further contributions to the growing scientific interest in technological acceptance factors from a German and/or South Korean perspective. Additionally, the approach in this study can serve as a framework for future culture-comparative studies to investigate the acceptance factors of different technologies. Due to the high predictive power observed in both countries, the proposed model could be used in other countries or in other technology-related research contexts. Lastly, the literature analysis included in this study provides an overview of current empirical mobile payment research and the acceptance factors already investigated in relation to the behavioral intention. Accordingly, it provides an overview of both significant and insignificant variables and supports researchers both in the selection of relevant factors and in the construction of new research models.

\section{References}

Agarwal, R. and Prasad J. (1999). Are individual differences germane to the acceptance of new information technologies? Decision Sciences, 30(2): 361-391. https://doi.org/10.1111/j.15405915.1999.tb01614.x

Akhtar, S., Irfan, M., Sarwar, A., Asma. and Rashid, Q. U. A. (2019). Factors influencing individuals' intention to adopt mobile banking in China and Pakistan: The moderating role of cultural values. Journal of Public Affairs, 19(1): e1884. https://doi.org/10.1002/pa.1884

Allied Market Research. (2018). Mobile payment market outlook 2023. Retrieved April 21, 2020, from https://www.alliedmarketresearch.com/mobile-payments-market

$\mathrm{Au}$, Y. A. and Kauffman, R. J. (2008). The economics of mobile payments: Understanding stakeholder issues for an emerging financial technology application. Electronic Commerce Research and Applications, 7(2): 141-164. https://doi.org/10.1016/j.elerap.2006.12.004 
Bailey, A. A., Pentina, I., Mishra, A. S. and Ben Mimoun, M. S. (2020). Exploring factors influencing US millennial consumers' use of tap-and-go payment technology. The International Review of Retail, Distribution and Consumer Research, 30(2): 143-163. https://doi.org/10.1080/09593969.2019.1667854

Bailey, A. A., Pentina, I., Mishra, A. S. and Mimoun, M. S. B. (2017). Mobile payments adoption by US consumers: an extended TAM. International Journal of Retail \& Distribution Management, 45(6): 1-17. https://doi.org/10.1108/ijrdm-08-2016-0144

Balz, B. (2019). Mobile Payments - In China Alltag, in Deutschland auf dem Vormarsch. Retrieved April 21, 2020, from https://www.bundesbank.de/de/presse/reden/mobile-payments-in-chinaalltag-in-deutschland-auf-dem-vormarsch-798102

Bauer, R.A. (1960, June 15, 16, 17) Consumer behavior as risk taking. In Hancock, R.S. (Ed.), Proceedings of the 43rd National Conference of the American Marketing Assocation (pp.389-398). Chicago, Illinois.

Chandra, S., Srivastava, S. and Theng, Y. L. (2010). Evaluating the role of trust in consumer adoption of mobile payment systems: An empirical analysis. Communications of the Association for Information Systems, 27. https://doi.org/10.17705/1CAIS.02729

Chawla, D. and Joshi, H. (2019). Consumer attitude and intention to adopt mobile wallet in India An empirical study. International Journal of Bank Marketing, 37(7): 1590-1618. https://doi.org/10.1108/IJBM-09-2018-0256

Chen, L. (2008). A model of consumer acceptance of mobile payment. International Journal of Mobile Communications, 6(1): 32-52. https://doi.org/10.1504/IJMC.2008.015997

Chin, W. W. (1998). The partial least squares approach for structural equation modeling. In Marcoulides GA (Ed.), Modern methods for business research [Nachdr] (pp. 294-336.) Lawrence Erlbaum.

Cohen, J. (1988). Statistical power analysis for the behavioral sciences. Lawrence Erlbaum Associates.

Crabbe, M., Standing, C., Standing, S. and Karjaluoto, H. (2009). An adoption model for mobile banking in Ghana. International Journal of Mobile Communications, 7(5): 515. https://doi.org/10.1504/IJMC.2009.024391

Dahlberg, T., Mallat, N, Ondrus, J. and Zmijewska, A. (2008). Past, present and future of mobile payments research: A literature review. Electronic Commerce Research and Applications, 7(2): 165-181. https://doi.org/10.1016/j.elerap.2007.02.001

Daştan, İ. and Gürler, C. (2016). Factors affecting the adoption of mobile payment systems: An empirical analysis. EMAJ: Emerging Markets Journal, 6(1): 17-24. https://doi.org/10.1016/j.procs.2015.10.002

Davis, F. D. (1989). Perceived usefulness, perceived ease of use, and user acceptance of information technology. MIS Quarterly, 13(3): 319. https://doi.org/249008

Dutot, V. (2015). Factors influencing Near Field Communication (NFC) adoption: An extended TAM approach. The Journal of High Technology Management Research, 26(1): 45-57. https://doi.org/10.1016/j.hitech.2015.04.005

Efron B. (1979). Bootstrap methods: Another look at the jackknife. The Annals of Statistics, 7(1): 126. https://doi.org/10.1214/aos/1176344552

eMarketer. (2019). Global mobile payment users 2019. Retrieved April 21, 2020, from https://www.emarketer.com/content/global-mobile-payment-users-2019

Falk, T., Kunz, W. H., Schepers, J. J. L. and Mrozek A. J. (2016). How mobile payment influences the overall store price image. Journal of Business Research, 69(7): 2417-2423. https://doi.org/10.1016/j.jbusres.2016.01.011

Fan, J., Shao, M., Li, Y. and Huang, X. (2018). Understanding users' attitude toward mobile payment use: A comparative study between China and the USA. Industrial Management \& Data Systems, 118(3): 524-540. https://doi.org/10.1108/IMDS-06-2017-0268 
Featherman, M. S. and Pavlou, P. A. (2003). Predicting e-services adoption: a perceived risk facets perspective. International Journal of Human-Computer Studies, 59(4): 451-474. https://doi.org/10.1016/S1071-5819(03)00111-3

Finken, S. and Heiduk, L. (2021). Factors influencing the acceptance of proximity mobile payment in Germany: The example of Apple Pay. Journal of Payments Strategy \& Systems, 15(1), 92108. https://www.econbiz.de/Record/factors-influencing-the-acceptance-of-proximity-mobilepayment-in-germany-the-example-of-apple-pay-finken-silke/10012582301

Fornell, C. and Larcker, D. F. (1981). Evaluating structural equation models with unobservable variables and measurement error. Journal of Marketing Research, 18(1): 39. https://doi.org/3151312

Fügl, M. (2020). Drivers of the use of proximity mobile payment: A comparative study of Germany and South Korea (Unpublished Master Thesis). Faculty of Business Management and Economics at JMU. Würzburg.

Gao, L. and Waechter, K. A. (2017). Examining the role of initial trust in user adoption of mobile payment services: an empirical investigation. Information Systems Frontiers, 19(3): 525-548. https://doi.org/10.1007/s10796-015-9611-0

Hair, J. F, Sarstedt, M., Ringle C.M. and Gudergan, S. (2018). Advanced issues in partial least squares structural equation modeling. Sage.

Hair, J. F., Hult, G. T. M., Ringle, C. M. and Sarstedt, M. (2017). A primer on partial least squares structural equation modeling (PLS-SEM). Second edition. Sage.

Hair, J. F., Ringle, C. M. and Sarstedt, M. (2011). PLS-SEM: Indeed a silver bullet. Journal of Marketing Theory and Practice, 19(2): 139-152. https://doi.org/10.2753/MTP10696679190202

Hair, J. F., Risher, J. J., Sarstedt, M. and Ringle, C. M. (2019). When to use and how to report the results of PLS-SEM. European Business Review, 31(1): 2-24. https://doi.org/10.1108/EBR-112018-0203

Hair, J. F., Sarstedt, M., Hopkins, L. and Kuppelwieser, V. G. (2014). Partial least squares structural equation modeling (PLS-SEM). European Business Review, 26(2): 106-121. https://doi.org/10.1108/EBR-10-2013-0128

Handarkho, Y. D. and Harjoseputro, Y. (2020). Intention to adopt mobile payment in physical stores Individual switching behavior perspective based on Push-Pull-Mooring (PPM) theory. Journal of Enterprise Information Management, 33(2): 285-308. https://doi.org/10.1108/JEIM-062019-0179

Henseler, J., Ringle, C. M. and Sarstedt, M. (2016). Testing measurement invariance of composites using partial least squares. International Marketing Review, 33(3): 405-431. https://doi.org/10.1108/IMR-09-2014-0304

Hofstede, G. (1991). Cultures and organizations: Software of the mind. McGraw-Hill.

Hsee, C. K. and Weber, E. U. (1999). Cross-national differences in risk preference and lay predictions. Journal of Behavioral Decision Making, 12(2): 165-179. https://doi.org/10.1002/(SICI)1099-0771(199906)12:2\%3C165::AID-BDM316\%3E3.0.CO;2$\mathrm{N}$

Humbani, M. and Wiese, M. (2018). A cashless society for all: Determining Consumers' readiness to adopt mobile payment services. Journal of African Business, 19(3): 409-429. https://doi.org/10.1080/15228916.2017.1396792

Im, I., Hong, S. and Kang, M. S. (2011). An international comparison of technology adoption. Information \& Management, 48(1): 1-8. https://doi.org/10.1016/j.im.2010.09.001

Kalinic, Z. and Marinkovic, V. (2016). Determinants of users' intention to adopt m-commerce: an empirical analysis. Information Systems and e-Business Management, 14(2): 367-387. https://doi.org/10.1007/s10257-015-0287-2 
Keramati, A., Taeb, R., Larijani, A. M. and Mojir, N. (2012). A combinative model of behavioural and technical factors affecting 'Mobile'-payment services adoption: an empirical study. The Service Industries Journal, 32(9): 1489-1504. https://doi.org/10.1080/02642069.2011.552716

Kerviler, G. de., Demoulin, N. T. M. and Zidda, P. (2016). Adoption of in-store mobile payment: Are perceived risk and convenience the only drivers? Journal of Retailing and Consumer Services, 31: 334-344. https://doi.org/10.1016/j.jretconser.2016.04.011

Kim, C., Mirusmonov, M. and Lee, I. (2010). An empirical examination of factors influencing the intention to use mobile payment. Computers in Human Behavior, 26(3): 310-322. https://doi.org/10.1016/j.chb.2009.10.013

Koenig-Lewis, N., Marquet, M., Palmer, A. and Zhao, A. L. (2015). Enjoyment and social influence: predicting mobile payment adoption. The Service Industries Journal, 35(10): 537-554. https://doi.org/10.1080/02642069.2015.1043278

Koenig-Lewis, N., Palmer, A. and Moll, A. (2010). Predicting young consumers' take up of mobile banking services. International Journal of Bank Marketing, 28(5): 410-432. https://doi.org/10.1108/02652321011064917

Lee, J. M. (2019). Determinants of mobile payment usage and the moderating effect of gender: Extending the utaut model with privacy risk. International Journal of Electronic Commerce Studies, 10(1): 43-64. http://dx.doi.org/10.7903/ijecs.1644

Leong, L. Y., Hew, T. S., Tan, G. W. H. and Ooi, K. B. (2013). Predicting the determinants of the NFC-enabled mobile credit card acceptance: A neural networks approach. Expert Systems with Applications, 40(14): 5604-5620. https://doi.org/10.1016/j.eswa.2013.04.018

Liébana-Cabanillas, F. and Lara-Rubio, J. (2017). Predictive and explanatory modeling regarding adoption of mobile payment systems. Technological Forecasting and Social Change, 120: 3240. https://doi.org/10.1016/j.techfore.2017.04.002

Liébana-Cabanillas, F., Marinkovic, V., Ramos-de-Luna, I. and Kalinic, Z. (2018). Predicting the determinants of mobile payment acceptance: A hybrid SEM-neural network approach. Technological Forecasting and Social Change, 129: 117-130. https://doi.org/10.1016/j.techfore.2017.12.015

Liébana-Cabanillas, F., Muñoz-Leiva, F. and Sánchez-Fernández, J. (2015a). Behavioral model of younger users in m-payment systems. Journal of Organizational Computing and Electronic Commerce, 25(2): 169-190. https://doi.org/10.1080/10919392.2015.1033947

Liébana-Cabanillas, F., Muñoz-Leiva, F. and Sánchez-Fernández, J. (2015c). Payment systems in new electronic environments: Consumer behavior in payment systems via SMS. International Journal of Information Technology \& Decision Making, 14(02): 421-449. https://doi.org/10.1142/S0219622015500078

Liébana-Cabanillas, F., Ramos-de-Luna, I. and Montoro-Ríos, F. (2017). Intention to use new mobile payment systems: a comparative analysis of SMS and NFC payments. Economic ResearchEkonomska Istraživanja, 30(1): 892-910. https://doi.org/10.1080/1331677X.2017.1305784

Liébana-Cabanillas, F., Ramos-de-Luna, I. and Montoro-Ríos, F. J. (2015b). User behaviour in QR mobile payment system: the QR Payment Acceptance Model. Technology Analysis \& Strategic Management, 27(9): 1031-1049. https://doi.org/10.1080/09537325.2015.1047757

Liébana-Cabanillas, F., Sánchez-Fernández, J. and Muñoz-Leiva, F. (2014). Antecedents of the adoption of the new mobile payment systems: The moderating effect of age. Computers in Human Behavior, 35: 464-478. https://doi.org/10.1016/j.chb.2014.03.022

Liu, Y., Wang, M., Huang, D., Huang, Q., Yang, H. and Li, Z. (2019b). The impact of mobility, risk, and cost on the users' intention to adopt mobile payments. Information Systems and e-Business Management, 17(2): 319-342. https://doi.org/10.1007/s10257-019-00449-0

Liu, Z., Ben, S. and Zhang, R. (2019a). Factors affecting consumers' mobile payment behavior: a meta-analysis. Electronic Commerce Research, 19(3): 575-601. https://doi.org/10.1007/s10660-019-09349-4 
Lu, X. and Lu, H. (2020). Understanding chinese millennials' adoption intention towards third-party mobile payment. Information Resources Management Journal, 33(2): 40-63. https://doi.org/10.4018/IRMJ.2020040103

Mallat N. (2007). Exploring consumer adoption of mobile payments - A qualitative study. The Journal of Strategic Information Systems, 16(4): 413-432. https://doi.org/10.1016/j.jsis.2007.08.001

Martens, M., Roll, O. and Elliott, R. (2017). Testing the technology readiness and acceptance model for mobile payments across Germany and South Africa. International Journal of Innovation and Technology Management, 14(06): 1750033. https://doi.org/10.1142/S021987701750033X

Moore, G. C. and Benbasat, I. (1991). Development of an instrument to measure the perceptions of adopting an information technology innovation. Information Systems Research, 2(3): 192-222. https://doi.org/10.1287/isre.2.3.192

Musa, A., Khan, H. U. and Al-Share, K. A. (2015). Factors influence consumers' adoption of mobile payment devices in Qatar. International Journal of Mobile Communications, 13(6): 670. https://doi.org/10.1504/IJMC.2015.072100

Nyaboga, A. B., Marwa, M. and Kabata, D. (2015). Motivational factors and use of mobile payment services in Kenya. Journal of Business and Economic Studies, 21(1/2): 40-50 http://repository.dkut.ac.ke:8080/xmlui/handle/123456789/598

Oliveira, T., Thomas, M., Baptista, G. and Campos, F. (2016). Mobile payment: Understanding the determinants of customer adoption and intention to recommend the technology. Computers in Human Behavior, 61: 404-414. https://doi.org/10.1016/j.chb.2016.03.030

Ozturk, A. B., Bilgihan, A., Salehi-Esfahani, S. and Hua, N. (2017). Understanding the mobile payment technology acceptance based on valence theory. International Journal of Contemporary Hospitality Management, 29(8): 2027-2049. https://doi.org/10.1108/IJCHM04-2016-0192

Park, C. and Jun, J. K. (2003). A cross-cultural comparison of Internet buying behavior. International Marketing Review, 20(5): 534-553. https://doi.org/10.1108/02651330310498771

Park, J., Amendah, E., Lee, Y. and Hyun, H. (2018). M-payment service: Interplay of perceived risk, benefit, and trust in service adoption. Human Factors and Ergonomics in Manufacturing \& Service Industries, 29(1): 31-43. https://doi.org/10.1002/hfm.20750

Pavlou, P. A. (2003). Consumer acceptance of electronic commerce: Integrating trust and risk with the technology acceptance model. International Journal of Electronic Commerce, 7(3): 101134. https://doi.org/10.1080/10864415.2003.11044275

Qasim, H. and Abu-Shanab, E. (2016). Drivers of mobile payment acceptance: The impact of network externalities. Information Systems Frontiers 18(5): 1021-1034. https://doi.org/10.1007/s10796-015-9598-6

Ramos-de-Luna, I., Liébana-Cabanillas, F., Montoro-Ríos, F. and Luz, A. P. R. G. (2015). Nuevas perspectivas sobre el comportamiento del consumidor para la adopción del pago móvil sin contacto. Desenvolve Revista de Gestão do Unilasalle, 4(1): 65-86. http://dx.doi.org/10.18316/1649

Ramos-de-Luna, I., Liébana-Cabanillas, F., Sánchez-Fernández, J. and Muñoz-Leiva, F. (2019). Mobile payment is not all the same: The adoption of mobile payment systems depending on the technology applied. Technological Forecasting and Social Change, 146: 931-944. https://doi.org/10.1016/j.techfore.2018.09.018

Ramos-de-Luna, I., Montoro-Ríos, F. and Liébana-Cabanillas, F. (2016). Determinants of the intention to use NFC technology as a payment system: an acceptance model approach. Information Systems and e-Business Management, 14(2): 293-314. https://doi.org/10.1007/s10257-015-0284-5

Ramos-de-Luna, I., Montoro-Ríos, F., Liébana-Cabanillas, F. and Luna, J. G.de. (2017). NFC technology acceptance for mobile payments: A Brazilian Perspective. Review of Business Management, 19(63): 82-103. https://doi.org/10.7819/rbgn.v0i0.2315 
Rodríguez-Entrena, M., Schuberth, F. and Gelhard, C. (2018). Assessing statistical differences between parameters estimates in Partial Least Squares path modeling. Quality \& Quantity, 52(1): 57-69. https://doi.org/10.1007/s11135-016-0400-8

Sanakulov, N. and Karjaluoto, H. (2017). A cultural comparison study of smartphone adoption in Uzbekistan, South Korea and Turkey. International Journal of Mobile Communications, 15(1): 85. https://doi.org/10.1504/IJMC.2017.080579

Sarstedt, M., Ringle, C. M. and Hair, J. F. (2017). Treating unobserved heterogeneity in PLS-SEM: A Multi-method approach. In Latan H, Noonan R (Eds.), Partial least squares path modeling: basic concepts, methodological issues and applications (pp.197-217). Springer International Publishing; Imprint: Springer.

Schierz, P. G., Schilke, O. and Wirtz, B. W. (2010). Understanding consumer acceptance of mobile payment services: An empirical analysis. Electronic Commerce Research and Applications, 9(3): 209-216. https://doi.org/10.1016/j.elerap.2009.07.005

Sellitto, C., Fong, M.W.L. and Phonthanukitithaworn, C. (2016). A comparative study of current and potential users of mobile payment services. SAGE Open, 6(4): 215824401667539. https://doi.org/10.1177/2158244016675397

Shin, D. H. (2009). Towards an understanding of the consumer acceptance of mobile wallet. Computers in Human Behavior, 25(6): 1343-1354. https://doi.org/10.1016/j.chb.2009.06.001

Shin, S. and Lee, W. (2014). The effects of technology readiness and technology acceptance on Nfc mobile payment services in Korea. Journal of Applied Business Research (JABR), 30(6): 1615. https://doi.org/10.19030/jabr.v30i6.8873

Slade, E., Williams, M., Dwivedi, Y. and Piercy, N. (2015). Exploring consumer adoption of proximity mobile payments. Journal of Strategic Marketing, 23(3): 209-223. https://doi.org/10.1080/0965254X.2014.9140

Smart Card Alliance. (2011). The Mobile Payments and NFC Landscape: A U.S. Perspective: A Smart Card Alliance Payments Council White Paper, Smart Card Alliance Inc., Princeton Junction. Retrieved April 21, 2020, from https://www.securetechalliance.org/publications-themobile-payments-and-nfc-landscape-a-us-perspective/

Statista. (2016). Mobile payment revenue worldwide 2015-2019. Retrieved April 21, 2020, from https://www.statista.com/statistics/226530/mobile-payment-transaction-volume-forecast/

Statista. (2019). Smartphone-Nutzung in Deutschland bis 2019. Retrieved April 21, 2020, from https://de.statista.com/statistik/daten/studie/198959/umfrage/anzahl-der-smartphonenutzer-indeutschland-seit-2010/

Steenkamp, J. B., Hofstede, F. T. and Wedel, M. (1999). A cross-national investigation into the individual and national cultural antecedents of consumer innovativeness. Journal of Marketing, 63(2): 55. https://doi.org/1251945

Straub, D., Keil, M. and Brenner, W. (1997). Testing the technology acceptance model across cultures: A three country study. Information \& Management, 33(1): 1-11. https://doi.org/10.1016/S0378-7206(97)00026-8

Streukens, S. and Leroi-Werelds, S. (2016). Bootstrapping and PLS-SEM: A step-by-step guide to get more out of your bootstrap results. European Management Journal, 34(6): 618-632. https://doi.org/10.1016/j.emj.2016.06.003

$\mathrm{Su}, \mathrm{P}$., Wang, L. and Yan J. (2018). How users' Internet experience affects the adoption of mobile payment: a mediation model. Technology Analysis \& Strategic Management, 30(2): 186-197. https://doi.org/10.1080/09537325.2017.1297788

Suh, B. and Han, I. (2002). Effect of trust on customer acceptance of Internet banking. Electronic Commerce Research and Applications, 1(3-4): 247-263. https://doi.org/10.1016/S15674223(02)00017-0

Sun, H. and Zhang, P. (2006). The role of moderating factors in user technology acceptance. International Journal of Human-Computer Studies, 64(2): 53-78. https://doi.org/10.1016/j.ijhcs.2005.04.013 
Tan, K.L., Memon, M.A., Sim, P.L., Leong, C. M., Soetrisno, F.K. and Hussain, K. (2019). Intention to use mobile payment system by ethnicity: A partial least squares multi-group approach. Asian Journal of Business Research, 36-59. https://www.researchgate.net/publication/332631469

Taylor, E. (2016). Mobile payment technologies in retail: a review of potential benefits and risks. International Journal of Retail \& Distribution Management, 44(2): 159-177. https://doi.org/10.1108/IJRDM-05-2015-0065

Teo, A.C., Tan, GW.H., Ooi, K.B., Hew, T.S. and Yew, K. T. (2015). The effects of convenience and speed in m-payment. Industrial Management \& Data Systems, 115(2): 311-331. https://doi.org/10.1108/IMDS-08-2014-0231

Thakur, R. and Srivastava, M. (2014). Adoption readiness, personal innovativeness, perceived risk and usage intention across customer groups for mobile payment services in India. Internet Research, 24(3): 369-392. https://doi.org/10.1108/IntR-12-2012-0244

Thatcher, J. B., Srite, M., Stepina, L.P. and Yongmei, L. I. U. (2003). Culture, overload and personal innovativeness with information technology: Extending the nomological net. Journal of Computer Information Systems, 44(1): 74-81. https://www.researchgate.net/publication/279767898_Culture_overload_and_personal_innova tiveness_with_information_technology_Extending_the_nomological_net

van der Heijden, $\bar{H}$., Verhagen, T. and Creemers, M. (2003). Understanding online purchase intentions: contributions from technology and trust perspectives. European Journal of Information Systems, 12(1): 41-48. https://doi.org/10.1057/palgrave.ejis.3000445

van Herk, H., Poortinga, Y. H. and Verhallen, T.M.M. (2005). Equivalence of survey data: relevance for international marketing. European Journal of Marketing, 39(3/4): 351-364. https://doi.org/10.1108/03090560510581818

Venkatesh V., Morris, M. G., Davis, G. B. and Davis, F. D. (2003). User acceptance of information technology: Toward a unified view. MIS Quarterly, 27(3): 425. https://doi.org/10.2307/30036540

Venkatesh, V., Thong, J. and Xu, X. (2012). Consumer acceptance and use of information technology: Extending the unified theory of acceptance and use of technology. Management Information Systems Quarterly, 36(1): 157-178. https://doi.org/10.2307/41410412

Verkijika, S. F. (2020). An affective response model for understanding the acceptance of mobile payment systems. Electronic Commerce Research and Applications, 39: 100905. https://doi.org/10.1016/j.elerap.2019.100905

Webster, J. and Watson, R. T. (2002). Analyzing the past to prepare for the future: Writing a literature review. MIS Quarterly, 26(2): 8-23. https://www.jstor.org/stable/4132319?seq=1\#metadata_info_tab_contents

Weiber, R. and Mühlhaus, D. (2014). Strukturgleichungsmodellierung: Eine anwendungsorientierte Einführung in die Kausalanalyse mit Hilfe von AMOS, SmartPLS und SPSS. 2, extended and revised. Springer Gabler.

Worldpay (n.d.). South Korea: Dive into payments tips and trends that make up the South Korean market. Retrieved April 21, 2020, from https://worldpay.globalpaymentsreport.com/en/marketguide/south-korea/

Wu, J., Liu, L. and Huang, L. (2017). Consumer acceptance of mobile payment across time. Industrial Management \& Data Systems, 117(8): 1761-1776. https://doi.org/10.1108/IMDS-08-20160312

Xin, H., Techatassanasoontorn, A. A. and Tan F. B. (2015). Antecedents of Consumer Trust in Mobile Payment Adoption. Journal of Computer Information Systems, 55(4): 1-10. https://doi.org/10.1080/08874417.2015.11645781

Ya, P. C., Li, Y. L. and Dong, H. Z. (2017). Understanding the intention to continue use of a mobile payment provider: An examination of Alipay wallet in China. International Journal of Business and Information, 12(4): 369-390. http://dx.doi.org/10.6702/ijbi.2017.12.4.2 
Yang, S., Lu, Y., Gupta, S., Cao, Y. and Zhang, R. (2012). Mobile payment services adoption across time: An empirical study of the effects of behavioral beliefs, social influences, and personal traits. Computers in Human Behavior, 28(1): 129-142. https://doi.org/10.1016/j.chb.2011.08.019

Yang, Y., Liu, Y., Li, H. and Yu, B. (2015). Understanding perceived risks in mobile payment acceptance. Industrial Management \& Data Systems, 115(2): 253-269. https://doi.org/10.1108/IMDS-08-2014-0243

Zhang, J. and Mao, E. (2020). Cash, credit, or phone? An empirical study on the adoption of mobile payments in the United States. Psychology \& Marketing, 37(1): 87-98. https://doi.org/10.1002/mar.21282

Zhou, T. (2011). The effect of initial trust on user adoption of mobile payment. Information Development 27(4): 290-300. https://doi.org/10.1177/0266666911424075

Zhou, T. (2013). An empirical examination of continuance intention of mobile payment services. Decision Support Systems, 54(2): $\quad$ 1085-1091. https://doi.org/10.1016/j.dss.2012.10.034

Zhou, T. (2014). Understanding the determinants of mobile payment continuance usage. Industrial Management \& Data Systems, 114(6): 936-948. https://doi.org/10.1108/IMDS-02-2014-0068

Zhu, K., Dong, S., Xu, S. X. and Kraemer, K. L. (2006). Innovation diffusion in global contexts: determinants of post-adoption digital transformation of European companies. European Journal of Information Systems. 15(6): 601-616. https://doi.org/10.1057/palgrave.ejis.3000650 